\title{
Hefur umhverfisvitund aukist? Viðhorf Íslendinga til umhverfismála og stóriðju 1987-2017
}

Sóllilja Bjarnadóttir, MA félagsfræđi, doktorsnemi í félagsfræđi, Háskóla Íslands

Inga Rún Sæmundsdóttir, MSc félagssálfræđi, verkefnisstjóri Félagsvísindastofnunar, Háskóla Íslands

Sigrún Ólafsdóttir, PHD félagsfræđi, prófessor, Háskóla Íslands

porvarður Árnason, PHD pverfaglegum umhverfisfræðum, forstöðumađur Rannsóknaseturs Háskóla Íslands á Hornafirđi

Guðbjörg Andrea Jónsdóttir, PHD félagssálfræđi, forstöđumađur Félagsvísindastofnunar, Háskóla Íslands

\section{Útdráttur}

Vægi umhverfismála í íslenskri pjóðmálaumræðu hefur aukist á undanförnum áratugum. Fram til pessa hefur ekki verið unnt að kanna með empirískum hætti hvort pessi aukna umræða endurspegli próun í átt til breyttra viðhorfa á meðal íslensks almennings. Gögn Íslensku kosningarannsóknarinnar (ÍSKOS) sýna skýrar langtíma breytingar í viðhorfum til umhverfismála á síðastliðnum prjátíu árum (1987-2017). Hér er fjallað um niðurstöður tveggja spurninga úr peirri könnun sem varða annars vegar viðhorf til pess að aðgerðir í umhverfismálum ættu að hafa forgang fram yfir aðgerðir til að auka hagvöxt og hins vegar viðhorf til pess hvort ríkisstjórnin ætti að leggja mikla eða litla áherslu á orkufreka stóriðju. Í báðum tilvikum sjást hliðstæðar breytingar yfir tíma; hlutfall peirra sem vilja leggja áherslu á umhverfismál eykst ár frá ári (með einni undantekningu strax eftir Hrunið) samhliða pví að hlutfall peirra sem vilja að ríkisstjórnin leggi mikla áherslu á stóriðju lækkar. Niðurstöður síðustu mælinga (2017) voru pær að 65\% 
svarenda vildu leggja áherslu á umhverfismál fram yfir hagvöxt og 80\% vildu að ríkisstjórnin legði litla áherslu á orkufreka stóriðju. Peir sem styðja vinstri flokka voru líklegri til að leggja áherslu á umhverfismál á meðan stuðningsfólk hægri flokka var líklegra til að leggja áherslu á stóriðju.

Efnisorð: Umhverfismál; stóriðja; Íslenska kosningarannsóknin (ÍSKOS).

\section{Has environmental awareness increased? Attitudes of the Icelandic public towards environmental issues and heavy industry 1987-2017}

\section{Abstract}

The significance of environmental issues in the Icelandic public debate has increased in recent decades. Until now, it has not been possible to empirically examine whether this increased debate reflects a development towards a change in attitudes among the Icelandic public. The data from the Icelandic National Election Study (ICENES) shows an apparent long-term change in attitudes towards environmental issues over the past thirty years (1987-2017). Here, we analyze the results of two questions from ICENES. Firstly, we investigate attitudes concerning whether environmental issues should take precedence over efforts to increase economic growth, and, secondly, views on whether the government should place great or little emphasis on heavy industry. Similar changes are seen over time; the proportion of those who want to prioritize environmental issues increases year by year (with one exception immediately after the economic crisis), and the proportion of those who want the government to emphasize heavy industry decreases. The last survey (2017) found that 65\% of respondents prioritized environmental issues above economic growth, and $80 \%$ wanted the government to place little emphasis on heavy industry. People who identified with a left political party where more likely to emphasize environmental issues whereas those who identified with a right political party where more likely to emphasize heavy industry.

Keywords: Environmental affairs; heavy industry; The Icelandic National Election study (ICENES).

\section{Inngangur}

Mannkynið stendur frammi fyrir fjölda umhverfisvandamála á heims- og/eða landsvísu, pau stærstu lúta að hnattrænum loftslagsbreytingum (IPCC 2013), eyðingu líffræðilegrar fjölbreytni (Walpole o.fl. 2010), mengandi, ósjálfbærum framleiðsluháttum og ofneyslu á náttúruauðlindum (Sustainable Europe Research Institute 2009). Hættur geta stafað af slíkum breytingum og pví er mikilvægt að fræðafólk reyni að skilja mögulegar lausnir (Dunlap 2015). Slíkar rannsóknir eru ekki einungis mikilvægar í fræðilegu tilliti heldur hafa einnig hagnýtt gildi við mótun árangursríkrar opinberrar stefnu í umhverfismálum (OECD 2001). 


\section{STJÓRNMÁL

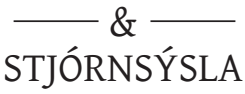

Kannanir á viðhorfum almennings til umhverfismála eiga sér talsvert langa sögu í Evrópu og Norður-Ameríku (Dunlap 2017). Í gegnum tíðina hefur félagsvísindafólk próað trausta, almenna mælikvarða á viðhorf til umhverfismála, meðal annars til pess að fylgjast með breytingum yfir tíma og til að bera saman viðhorf fólks í ólíkum löndum (Telesiene \& Gross 2017). Hugtakið umhverfishygð (e. environmental concern) vísar til pess: „í hvaða mæli fólk er sér meðvitað um vandamál sem varða umhverfið og styður aðgerðir til að leysa pau og/eða sýnir fram á vilja sinn til að leggja sjálft eitthvað af mörkum peim til lausnar“ (Porvarður Árnason 2004, 6). Umhverfisverndarhyggja (e. environmentalism) byrjaði að skjóta rótum á Íslandi á sjöunda og áttunda áratug síðustu aldar, líkt og víðast hvar í nágrannalöndum okkar (Porvarður Árnason 2004; Helgi Hallgrímsson 2010). Um svipað leyti hófust deilur um fyrirhugaðar virkjanaframkvæmdir við Laxá í Aðaldal og í Djórsárverum (Unnur Birna Karlsdóttir 2010). Segja má að petta tvennt - aukin vitund almennings um umhverfismál og deilur innan samfélagsins um einstakar virkjanaframkvæmdir - marki upphaf nútíma umhverfisverndar á Íslandi.

Fræðafólk hefur bent á að eftir pví sem samfélög próast breytast viðhorf og væntingar almennings. Par hefur verið skoðað hvernig gildi próast yfir í að verða póstmódernísk pegar próunarstig samfélaga verður hærra, en pá er aukin áhersla á lífsgæði fram yfir раð að lifa af. Með pví eykst einnig áhersla á mannréttindi, kynjajöfnuð og umhverfismál (Inglehart 1990). Inglehart (1995) vekur athygli á pví að togstreita eða deilur geti skapast innan samfélags pegar pað parf að fórna umhverfinu fyrir hagvexti eða öfugt. Í einhverjum tilvikum er hægt að vernda umhverfið án pess að pað komi niður á hagvexti en pá er auðveldara fyrir stjórnvöld að setja skýra stefnu. Vandinn skapast pegar stjórnvöldum er ýtt út í pað að velja á milli. Pessar erfiðu ákvarðanir leiða „til pess að umhverfisvernd verður að pólitísku viðfangsefni“ (Inglehart 1995, 59).

Töluverður fjöldi rannsókna hefur leitast við að kanna hvort ný umhverfisgildi hafi komið fram á sjónarsviðið á undanförnum áratugum. Par hefur einkum verið skoðað hvort visthverf (e. ecocentric) gildi hafi fengið aukið vægi í vestrænum samfélögum, pá á kostnað mannhverfra (e. anthropocentric) gilda (Dorvarður Árnason 2005). Fyrstu rannsóknir af pessum toga byggðu á notkun New Environmental Paradigm (NEP) kvarðans (Dunlap \& Van Liere 1978), en honum var ætlað að kanna hvort greina mætti grundvallarbreytingu á viðhorfum til náttúrunnar á meðal almennings og er sá mælikvarði á umhverfishygð sem mest hefur verið notaður á alpjóðavísu (Dunlap 2008). Um miðjan níunda áratuginn hófust síðan rannsóknir á mögulegum breytingum á gildismati almennings, annars vegar með hliðsjón af gildakvarða Schwartz (Stern \& Dietz 1994; Schultz 2001) og hins vegar með notkun ýmissa kvarða sem lutu að greiningu nýrra umhverfisgilda (Grenstad \& Wollebæk 1998; Minteer \& Manning 1999). Lýðfræðilegir og/eða pólitískir pættir geta einnig skipt máli; rannsóknir erlendis hafa pannig t.d. sýnt að einstaklingar sem skilgreina sig til vinstri á hinum pólitíska skala hafa að jafnaði jákvæðari viðhorf til umhverfisins samanborið við pá sem hallast meira til hægri (Fairbrother 2017; Neymayer 2003; Torgler \& García-Valiñas 2007).

Раð аð einstaklingur sé umhverfisverndarsinni getur haft margvíslega merkingu (Porvarður Árnason 2004, 2005). Par getur bæði verið um almenna umhverfisverndarhygð 
að ræða en einnig andstöðu við einstakar framkvæmdir. Framkvæmdir vegna stóriðju, sem er umfangsmikil iðnaðarframleiðsla sem helst yfirleitt í hendur við mikla orkunotkun, hafa nær undantekningarlaust leitt til átaka í íslenskri pjóðmálaumræðu. Málmbræðslur eins og álver eru dæmi um stóriðju af pessum toga. Vatnsaflsvirkjanir hafa verið umdeildar á Íslandi allt frá pví að fyrstu hugmyndir um slíkar virkjanir komu fram undir lok 19. aldar (Unnur Birna Karlsdóttir 2010). Um 1970 urðu ákveðin páttaskil í umræðunni með stofnun fyrstu náttúruverndarsamtaka hérlendis (Helgi Hallgrímsson 2010) og síðan pá hefur andstaða við virkjanaframkvæmdir, einkum á óbyggðum víðernum innan miðhálendisins, verið pungamiðjan í starfi slíkra samtaka. Stórvirkjanir eins og Kárahnjúkavirkjun spiluðu par stórt hlutverk og umhverfismálin sem höfðu fram að pví verið á jaðri íslenskrar stjórnmálaumræðu urðu á skömmum tíma mun meira áberandi (Ólafur P. Hardarson \& Gunnar Helgi Kristinsson 2003). Áhugavert er að sjá hvort einhver tenging gæti verið á milli umhverfismála og framkvæmda til að auka hagvöxt en fræðafólk hefur sýnt að pessi tvö málefni virðast oft mynda andstæða póla í umræðu almennings (Ólafur P. Hardarson \& Gunnar Helgi Kristinsson 2003; Jón Ólafsson 2006).

Í pessari grein skoðum við sérstaklega breytingar á viðhorfum Íslendinga til umhverfismála yfir prjátíu ára tímabil og setjum viðhorfin í pólítískt samhengi. Út frá pessu spyrjum við tveggja rannsóknarspurninga: 1) Hvernig hafa viðhorf á Íslandi breyst og tengjast pau staðbundnum málefnum á Íslandi? og 2) Hvernig tengjast viðhorf til umhverfismála kosningahegðun einstaklinga? Pessum spurningum svörum við með pví að skoða breytingar á viðhorfum yfir tíma og með tvíkosta aðhvarfsgreiningu um hvernig pessi málefni hafa próast með gögnum frá Íslensku kosningarannsókninni (ÍSKOS).

\section{Fræðilegt yfirlit}

\subsection{Hvernig urðu umhverfismál pólitískt ágreiningsmál á Íslandi?}

Færð hafa verið rök fyrir pví að samfélagslegar umræður séu aldrei staðbundnar, heldur taki mið af hvað er að gerast í öðrum löndum. Pannig urðu kjarnorkuslysið í Chernobyl 1986 og olíulekinn vegna strands Exxon Valdes við Alaska 1989 til pess að auka vitund almennings um umhverfismál víða um heim (Auður Ingólfsdóttir 2008). Prátt fyrir að umhverfismál séu alpjóðlegt málefni, pá skipta staðbundnar aðstæður engu að síður máli. Đví er mikilvægt að gefa yfirlit yfir próun í íslensku samfélagi síðan umhverfismál komu fram sem pólítískt ágreiningsmál, par sem staðbundnar umræður eru líklegar til að hafa áhrif á viðhorf almennings til umhverfismála. Par má nefna að örar framfarir í smíði togara urðu til pess að fjöldi frystitogara við landið nær tvöfaldaðist á árabilinu 1985-1990 og fiskvinnsla í landi minnkaði samhliða (Nordic Council of Ministers 2018). Fiskveiðistjórnunarkerfið, eða kvótakerfið, sem tekið var upp með reglugerð árið 1984 var fest í sessi með lögum nr. 38/1990 en pá var fiskveiðikvótinn tengdur aflareynslu báta og verslun með aflakvóta á milli útgerða var heimiluð (Skúli Magnússon 1997; Lög nr. 38/1990). Samlegðaráhrif pessa ollu pví að smábátaútgerð í sjávarbyggðum landsins átti undir högg að sækja. Pessi próun leiddi til aukins atvinnuleysis á landsbyggðinni og sá fólksflótti sem fylgdi í kjölfarið kallaði á atvinnuskapandi lausnir. Árið 1989 voru uppi áform um nýtt álver á Íslandi og var Reyðarfjörður á meðal peirra staða sem komu til 
álita. Margir Reyðfirðingar og aðrir Austfirðingar beittu sér fyrir byggingu álvers par og voru helstu rökin efnahagslegur ávinningur og jákvæð áhrif á byggða- og atvinnupróun (Ísak Ólafsson 1990; Morgunblaðið 1999). Alcoa Fjarðaál hóf rekstur á Reyðarfirði árið 2007 (Iceland e.d.).

Orðið „stóriðjustefna“ heyrist iðulega í opinberri umræðu á Íslandi í peirri merkingu að um sé að ræða meðvitaða, langtíma stefnu stjórnvalda um uppbyggingu orkufreks iðnaðar. Unnur Birna Karlsdóttir (2010, 205-206) lýsir hér stöðu mála á peim tíma pegar stóriðjustefnan hérlendis lét einna mest að sér kveða:

Virkjanir voru á síðari hluta níunda áratugarins orðnar markmið í sjálfu sér, sem atvinnugrein og auðlindanýting, eins og birtist í stefnu stjórnvalda að láta virkja eingöngu til raforkuframleiðslu fyrir álver eða aðra orkufreka atvinnustarfsemi. Yfirvöld orkumála leituðust pví við að stuðla að byggingu stórra virkjana og með pví skapa eftirspurn eftir raforku hér á landi. Баð var gert með pví að markaðssetja Ísland erlendis sem land nægrar og ódýrrar vatnsorku í peim tilgangi að laða hingað erlenda stóriðju til að kaupa orku í miklum mæli. Fall jökulánna varð markaðsvara á alpjóðlegum orkumarkaði.

Unnið var að virkjanaframkvæmdum við Kárahnjúka samhliða byggingu álversins í Reyðarfirði . Dær framkvæmdir hófust undir árslok 2002 og var virkjunin gangsett 2007. pessar tvær tengdu framkvæmdir kölluðu til samans á stærstu einstöku fjárfestingu Íslandssögunnar (Ásgeir Jónsson o.fl. 2018). Í kjölfar pessa sérlega djúpstæða ágreinings meðal landsmanna um byggingu Kárahnjúkavirkjunar virðast hafa orðið ákveðin páttaskil í umhverfisvernd hér á landi (Karl Benediktsson 2008). Ólafur P. Harðarson og Gunnar Helgi Kristinsson $(2003,976)$ lýsa pessum páttaskilum með eftirfarandi hætti:

Um petta mál urðu mikil átök í íslenskum stjórnmálum, til marks um nýtt klofningsmál - umhverfismál - sem var einungis minniháttar málefni fimm árum fyrr í íslenskum stjórnmálum. Fluttar voru nær 400 ræður um efnið (tekur ekki til nefndafunda) á Alpingi, par sem 63 alpingismenn sitja, sem gefur til kynna hversu alvarlega málefnið var tekið.”1 Fleira fræðafólk hefur tekið í sama streng, par á meðal Jón Ólafsson (2006) sem taldi Kárahnjúkadeiluna hafa markað grundvallarbreytingu og að andstaðan við pær framkvæmdir hafi hreinlega búið til umhverfisvernd á Íslandi.

Bygging álvera og annarra stóriðjumannvirkja hefur verið umdeild bæði vegna ýmissa umhverfissjónarmiða en ekki síður vegna eignarhalds erlendra á slíkum verksmiðjum. Röksemdir peirra sem hafa verið hliðhollir slíkum framkvæmdum hafa á hinn bóginn gjarnan hverfst um tekjur af orkusölu og aukinn útflutning, auk atvinnusköpunar og eflingu byggða. Í skýrslu iðnaðarráðuneytisins frá árinu 2009 um áhrif stóriðjuframkvæmda á íslenskt efnahagslíf eru breytingar á meðaltalsvægi útflutningsvara á árabilinu 1969-2008 dregnar fram. Par má meðal annars sjá ört vaxandi vægi áls (9,7-27,8\%) og minnkandi vægi sjávarafurða (48,5-26,2\%) á tímabilinu (iðnaðarráðuneytið 2009, 14). Ferðapjónustan var lengi eftirbátur meginútflutningsstoðanna tveggja, sjávarafurða og 
áls, en árið 2012 höfðu heildarútflutningstekjur ferðapjónustunnar farið fram úr álútflutningi og árið 2013 voru tekjur af ferðapjónustu meiri en tekjur af sjávarafurðum (Hagfræðideild Landsbankans 2013). Undanfarinn áratug hafa pólitískar áherslur á hagrænt mikilvægi talsvert færst frá álframleiðslu yfir á ferðapjónustu á Íslandi. Samhliða pví hafa friðlýst svæði fengið aukið vægi sem ein af meginstoðum íslenskrar ferðapjónustu og par með mikilvæg uppspretta tekna fyrir pjóðarbúið (Siltanen 2018; Auður H. Ingólfsdóttir o.fl. 2019). Pá hafa hugmyndir um hagvöxt og forsendur hans breyst talsvert, með meiri áherslu á ,grænan vöxt“ (OECD 2011) og „hringrásarhagkerfið“ (Umhverfisstofnun e.d.; Stjórnarráð Íslands 2021).

Frekari stjórnsýsluleg áhrif má sjá í áherslubreytingum í starfsemi ráđuneyta á pví tímabili sem greinin fjallar um. Árið 1990 var umhverfisráðuneytið stofnað og árið 2012 var pví breytt í umhverfis- og auðlindaráðuneytið en pá fluttust rannsóknir á auðlindum og ráðgjöf um nýtingu peirra til ráðuneytisins sem var í pví sambandi falið að setja viðmið um sjálfbæra nýtingu allra auðlinda (Iceland e.d). Að lokum er líklegt að Hrunið hafi dregið úr vægi umhverfismála í huga almennings, að minnsta kosti pegar umhverfisvernd er stillt upp sem andstæðu hagvaxtar. Í skrifum sínum um póstmateríalisma setur Inglehart (1983, 2008) fram pá tilgátu að efnahagslegur samdráttur geti haft skaðleg áhrif á póstmaterialísk gildi, par með talda umhverfishygð, par sem kreppuástand geti tímabundið leitt til aukinnar áherslu á efnishyggju. Petta staðfestir Kenny (2020) í rannsókn sinni á forgangsröðun almennings í um 20 löndum á umhverfi fram yfir hagvöxt og atvinnusköpun fyrir og eftir hrun. Hins vegar sýna Guerra, Schmidt og Valente (2017) fram á að umhverfisvernd og hagvöxtur eru síður talin mynda andstæðupar í peim Evrópulöndum par sem velmegun er mest. Í pví óvenju mikla atvinnuleysi og efnahagsprengingum sem fylgdu í kjölfar bankahrunsins má ætla að almenningur teldi ástæðu til að stjórnvöld legðu áherslu á aðgerðir til að styrkja efnahag landsins. Út frá pessari próun setjum við fram tvær tilgátur.

Tilgáta 1. Viðhorf almennings breytist i k.jölfar Hrunsins pannig ad hlutfall peirra sem vill leggja áherslu á hagvöxt umfram umbverfismál eykst.

Tilgáta 2. Breytingar verda á vidhorfi fólks til orkufrekrar stóridju yfir tíma (frá 1987-2017) pannig ad blutfall peirra sem vill leggja áberslu á orkufreka stóridju minnkar.

\subsection{Umhverfismál sem átök í stjórnmálum}

раð hefur verið umdeilt innan fræðasamfélagsins hvernig eigi að varpa ljósi á breytingar á viðhorfi einstaklinga til umhverfisins. Rannsóknirnar hafa að mestu leyti byggt á premur kenningarlegum römmum, kenningu Inglehart (1995) um breytingu á póstmódernískum gildum innan samfélaga, hugmyndum Dunlap og Mertig (1997) um hvernig peir telja umhverfisvitund vera orðið hnattrænt fyrirbæri og hugmyndir Diekmann og Franzen (1999) um velgengniskenninguna. Inglehart (1995) hefur fært rök fyrir pví að smátt og smátt hafi orðið ákveðin breyting í gildum og markmiðum einstaklinga, par sem gæði lífsins vega pyngra en hagvöxtur og neysla. Hann nefnir að ein ástæða fyrir pessari breyt- 


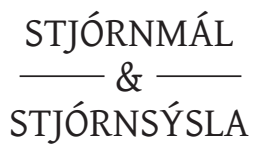

ingu á gildum er aukin umhverfisvitund. Hann benti enn fremur á að vandi skapast hjá stjórnvöldum pegar peim er ýtt í pað að velja á milli umhverfisverndar og hagvaxtar (Inglehart 1995, 59). Hér verður að hafa hugfast að umhverfismálin sem slík eru í stöðugri próun og erlendar rannsóknir hafa sýnt að áhyggjur af umhverfinu jukust eftir 1990 (Wray-Lake o.fl. 2010). Skýrt dæmi um pað er vægi loftslagsmála (hamfararhlýnunar) og plastmengunar í samtímaumræou, en pessi umhverfisvandamál voru mun minna í sviðsljósinu um aldamótin síðustu en pau eru nú. Ýmsar vísbendingar eru til staðar um að ákveðin grundvallarbreyting hafi átt sér stað í viðhorfum íslensks almennings til stórra virkjana og/eða stóriðju í kringum aldamótin síðustu (Ólafur P. Hardarson \& Gunnar Helgi Kristinsson 2003), sem líklega tengist hugmyndum Inglehart um togstreitu á milli umhverfisverndar og hagvaxtar. Ekki er pó ljóst hvort sú breyting laut að umhverfishygð almennt eða aðeins að byggingu Kárahnjúkavirkjunar og álversins í Reyðarfirði. Мeð pví að rannsaka hvernig viðhorf hafa breyst yfir tíma er hægt að fá betri innsýn í pað hvaða einstakar framkvæmdir eða deilumál höfðu áhrif á próun umhverfismála hér á landi. Byggjum við pað upp á hugmyndum Inglehart um hvernig einstaka mál verða deilumál innan samfélaga pegar stjórnvöld purfa að velja á milli umhverfisverndar og hagvaxtar. Dunlap og Mertig (1997) hafa fært mótrök við pessari kenningu og telja að umhverfisvitund sér orðið hnattrænt fyrirbæri par sem fólk alls staðar hefur meiri áhyggjur af umhverfinu, óháð félagslegri stöðu. Priðja skýringin á hvernig umhverfisviðhorf hafa breyst yfir tíma er velgengniskenningin (Diekmann \& Franzen 1999), en kenningin leggur áherslu á pað hvernig áhyggjur einstaklinga af umhverfinu verða meiri pegar velmegun eykst.

раð eru pví ýmsar rannsóknir sem hafa skoðað umhverfisviðhorf einstaklinga en eitt stöðugasta sambandið yfir tíma hefur verið á milli stjórnmálaskoðana og umhverfisverndar. Rannsóknir erlendis sýna að peir sem eru til vinstri í stjórnmálum eru líklegri en peir sem eru til hægri til að sampykkja að borga hærri skatta í págu umhverfisverndar (Fairbrother 2017), hafa meiri vilja til að koma í veg fyrir skemmdir á umhverfinu (Torgler \& García-Valiñas 2007), hafa meiri áhyggjur af umhverfinu (Xiao \& McCright 2015) og eru meðvitaðri um umhverfismál (Neymayer 2003). Раð virðist pví vera að peir sem eru vinstri sinnaðir séu líklegri en peir sem eru hægri sinnaðir til að vilja vernda umhverfið. Fairbrother (2017) bendir einnig á að traust innan samfélaga, og pá sérstaklega vantraust til ríkisstjórnarinnar, geti haft áhrif á viðhorf til reglugerða pegar kemur að umhverfinu. Einstaklingar eiga oft erfitt með að trúa pví að ríkisstjórnin muni standa við pað sem hún segir og dregur pað úr jákvæðu viðhorfi gagnvart auknum aðgerðum stjórnvalda til verndar umhverfinu. Hér skoðum við sérstaklega hvort pað hafi áhrif á viðhorf einstaklinga hvaða flokk peir kusu í síðustu kosningum. Líklegt má telja að peir flokkar sem eru til vinstri leggi meiri áherslu á umhverfismál, en peir til hægri leggi frekar áherslu á orkufreka stóriðju. Í nýlegri íslenskri rannsókn kom fram sama samband hér og erlendis par sem peir sem staðsetja sig til vinstri eru líklegri til að vilja fórna eigin tekjum til að vernda umhverfið samanborið við pá sem staðsetja sig til hægri (Sóllilja Bjarnadóttir 2020). Í ljósi pessa setjum við fram tvær tilgátur: 
Tilgáta 3. Kjósendur flokeka sem eru lengra til vinstri eru líklegri til pess ad velja umbverfi fram yfir haguöxt miðad við pá sem eru stadsettir hagra megin sem eru likelegri til að velja haguöxt fram yfir umbverfi.

Tilgáta 4. Kjósendur flokeka sem eru stadsettir til vinstri eru likelegri til pess að vilja ekeki leggja aukna áherslu á orkufreka stóridju midad vid pá sem eru stadsettir hagra megin sem eru likklegri til à̃ vilja leggja aukna áherslu á orkufreka stóridju.

\section{3 Áhrif annarra pátta á umhverfisviðhorf}

Áhersla okkar er á breytingar á viðhorfum yfir tíma og hvernig stjórnmál og hugsanlega átök í stjórnmálum hafa haft áhrif á viðhorf almennings. Engu að síður er mikilvægt að stjórna fyrir ákveðnum grunnbreytum sem fyrri rannsóknir hafa tengt við umhverfisviðhorf og munum við í stuttu máli gera grein fyrir niðurstöðum peirra. Konur virðast hafa jákvæðari viðhorf til umhverfismála, vera líklegri til að leggja sitt af mörkum til umhverfisverndar (Torgler o.fl. 2008) og hafa meiri áhyggjur af ástandi umhverfismála, (McCright \& Dunlap 2011, 2013; McCright \& Xiao 2014; Xiao \& McCright 2015). Fyrri rannsóknir erlendis hafa sýnt að yngra fólk (Carlsson \& Johansson-Stenman 2000; Gelissen 2007) og peir sem eru með hærra menntunarstig séu líklegri til að hafa jákvæð viðhorf til umhverfisverndar (Gelissen 2007; Torgler \& García-Valiñas 2007). Samband búsetu og umhverfishygðar er ekki jafn skýrt. Dó eldri rannsóknir hafi sýnt að peir sem bjuggu í péttbýli höfðu meiri áhyggjur af umhverfinu en peir sem bjuggu í dreifbýli (Howell \& Laska 1992; Tremblay \& Dunlap 1978) hafa nýrri rannsóknir ekki fundið slíkt samband (Kennedy o.fl. 2009; Xiao \& McCright 2007). Erlendar rannsóknir hafa einnig sýnt að fólk í hærri launaflokkum sé líklegra til að vilja borga hluta af launum sínum til umhverfisverndar en peir sem minni tekjur hafa (Fairbrother 2013), hins vegar var sambandið mjög veikt og ekki marktækt fyrir allar víddir hugtaksins sem var notað.

Í pessari rannsókn beinum við sjónum að pví hvort og pá hvernig viðhorf almennings til umhverfismála og stóriðju hafa breyst samhliða pólitískum og efnahagslegum áherslubreytingum á síðustu áratugum. Einnig munum við kanna hvort munur er á viðhorfum til umhverfismála og stóriðju út frá pví hvaða flokk einstaklingar kusu í síðustu kosningum.

\section{Aðferð}

\section{1 pátttakendur}

Dátttakendur í Íslensku kosningarannsókninni eru valdir með einföldu tilviljunarúrtaki úr pjóðskrá (Hardarson 1995), venjulega á milli 2-3000 manns í hvert sinn en árið 2017 var úrtakið 4000 manns. Félagsvísindastofnun Háskóla Íslands annaðist gagnaöflun öll árin að undanskildum árunum 2007 og 2009. Árið 2007 sá Miðlun um gagnaöflun og árið 2009 sá Rannsóknarmiðstöðin á Bifröst um öflun gagna. 
Sóllilja Bjarnadóttir, Inga Rún Sæmundsdóttir,

Sigrún Ólafsdóttir, porvarđur Árnason og

Guðbjörg Andrea Jónsdóttir

\&

STJÓRNSÝSLA

Tafla 1. Fjöldi í úrtaki, svarhlutfall og gagnaöflunartími árin 1987-2017

\begin{tabular}{lcccc}
\hline Ár & Fjöldi í úrtaki & Svarhlutfall & Dagsetning kosninga & Gagnaöflunartímabil \\
\hline 1987 & 2.482 & $75 \%$ & 25. apríl & 1. maí - 30. maí \\
1991 & 2.000 & $75 \%$ & 20. apríl & 3. maí - 31. maí \\
1995 & 2.400 & $71 \%$ & 8. apríl & 19. apríl - 2. maí \\
1999 & 2.300 & $71 \%$ & 8. maí & 8. maí - 30. júní \\
2003 & 2.300 & $63 \%$ & 10. maí & 13. maí - 25. júní \\
2007 & 2.600 & $61 \%$ & 12. maí & 2. júní - 22. ágúst \\
2009 & 2.600 & $53 \%$ & 25.apríl & 7. maí - 31. ágúst \\
2013 & 2.600 & $57 \%$ & 27. apríl & 4. maí - 10. september \\
2016 & 2.600 & $51 \%$ & 29. október & 30. október - 25. janúar \\
2017 & 4.000 & $53 \%$ & 27. október & 30. október - 2. febrúar \\
\hline Samtals & $\mathbf{2 3 . 8 8 2}$ & $63 \%$ & & \\
\hline
\end{tabular}

Tafla 1 sýnir að svarhlutfall hefur farið lækkandi og var komið niður í 51\% árið 2016 og pví var brugðið á pað ráð að stækka úrtakið árið 2017 til að tryggja nægan fjölda svarenda fyrir flóknari tölfræðigreiningar. 
Tafla 2. Skipting svarenda eftir árum út frá bakgrunni, stuđningi við stjórnmálaflokk og viðhorfa til umhverfismála fram yfir hagvöxt og stóriðju

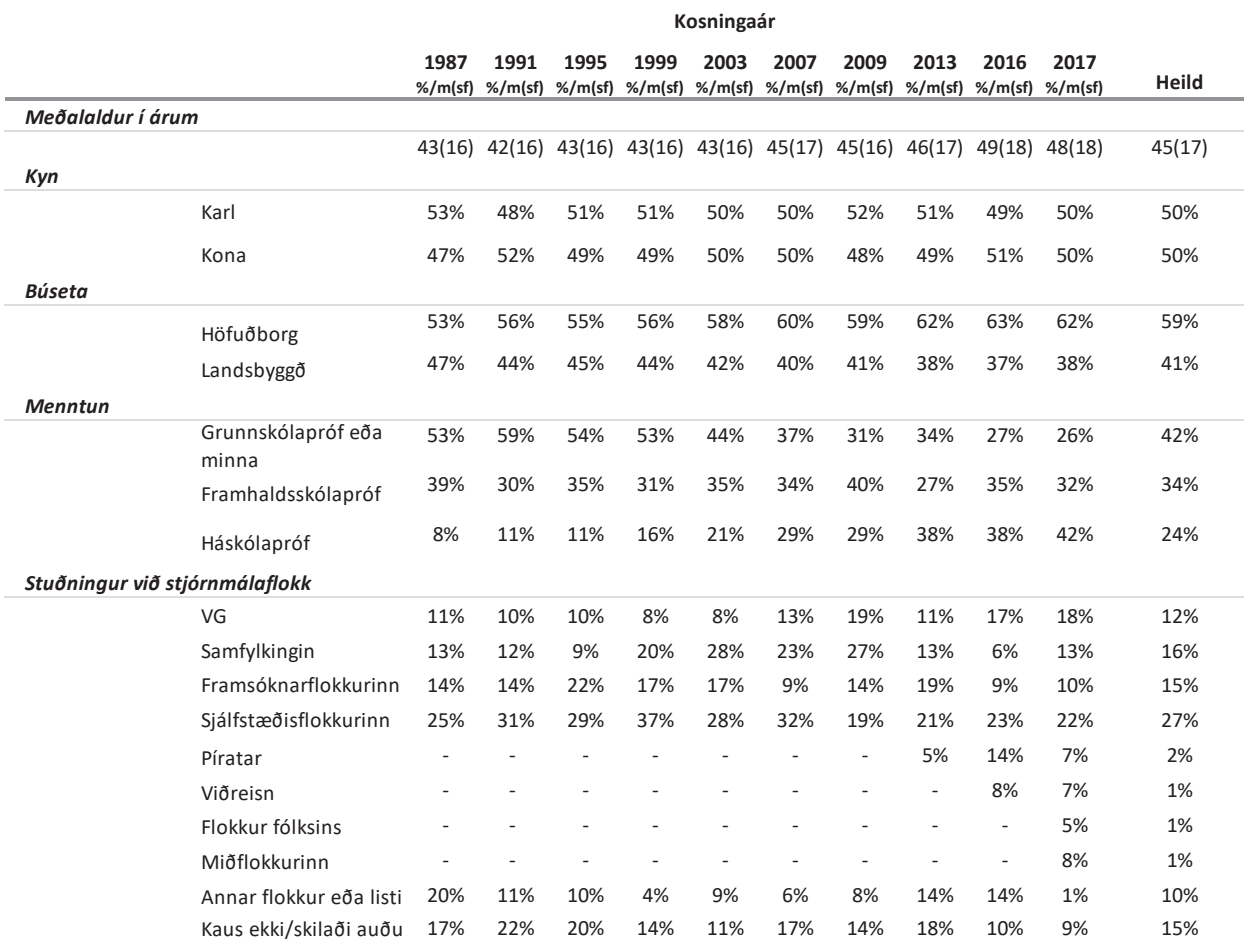

Umhverfismál fram yfir hagvöxt (međaltal og staðalfrávik á kvarđa 1 (Alveg sammála) til 5 (Alveg ósammála))

$\begin{array}{lllllllllll}2,7 & 2,6 & 2,8 & 2,6 & 2,8 & 2,6 & 3,2 & 2,9 & 2,3 & 2,3 & 2,7\end{array}$

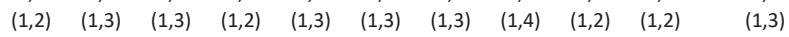

Áhersla á stóriđju (međaltal og staðalfrávik á kvarđa 1 (Mjög mikla áherslu) til 5 (Mjög litla/enga áherslu))

Heildarfjöldi svarenda

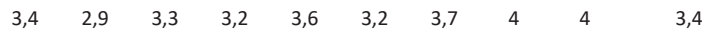

$\begin{array}{llllllllll}(1,3) & (1,2) & (1,2) & (1,1) & (1,0) & (1,2) & (1,1) & (1) & (0,9) & (1,2)\end{array}$

$\begin{array}{lllllllllll}1745 & 1491 & 1721 & 1631 & 1446 & 1595 & 1385 & 1479 & 1295 & 2073 & 15861\end{array}$

Tafla 2 sýnir að meðalaldur pátttakenda hefur farið heldur hækkandi, var 43 ár 1987 en 48 ár 2017. Petta er til marks um hækkandi aldur pjóðarinnar en skýrist pó einnig að nokkru leyti af lækkandi svarhlutfalli í yngstu aldurshópunum undanfarin ár. Kynjaskipting er nokkuð jöfn, í heildina 50,5\% karlar og 49,5\% konur. Búseta pátttakenda endurspeglar að nokkru leyti pá búsetupróun sem átt hefur sér stað á tímabilinu frá 1987 til 2017 en pó hefur svarhlutfall verið heldur lægra á höfuðborgarsvæðinu en á landsbyggðinni. Árið 1987 var yfir helmingur svarenda með grunnskólapróf eða minna og einungis $8 \%$ með háskólamenntun. Árið 2017 er hlutfall háskólamenntaðra í hópi svarenda orðið 42\% og hlutfall peirra sem ekki hafa lokið neinu formlegu námi eftir grunnskólapróf komið niður í 26\%. Nokkur breyting hefur orðið á stuðningi við stjórnmálaflokka par sem nýir 


\section{STJÓRNMÁL \& \\ STJÓRNSÝSLA}

flokkar hafa komið inn á sjónarsviðið á sama tíma og fjórflokkurinn sýnir breytilegt hlutfall kjósenda á bak við sig. Dannig var fjórflokkurinn með um eða uppúr 90\% fylgi á árunum 1999 til 2007 en pað fer dalandi eftir hrun og mælist lægst árið 2016 (61\%).

\section{Mælitæki}

Fylgibreyturnar í greiningunni eru tvær spurningar sem mæla viðhorf til umhverfismála og stóriðju. Fyrri spurningin er „Ertu sammála pví eða ósammála, að á næstu árum ættu aðgerðir í umhverfismálum að hafa forgang fram yfir tilraunir til að auka hagvöxt, eða finnst pér petta ekki skipta máli?“ Svarmöguleikar eru fimm á Likert kvarða par sem einn stendur fyrir „Alveg sammála“ og fimm stendur fyrir „Alveg ósammála“. Spurningin var lögð fyrir í Íslensku kosningarannsókninni á árunum 1987 til 2017 í óbreyttri mynd. Spurning tvö var að mestu leyti óbreytt frá 1991 til 2017 og er svohljóðandi „Finnst pér að ríkisstjórnin ætti að leggja mikla, nokkra eða litla áherslu á orkufreka stóriðju?" Svarmöguleikar eru fimm á Likert kvarða par sem einn stendur fyrir „Mjög mikla áherslu“ og fimm stendur fyrir „Mjög litla áherslu (enga áherslu)“. Árið 1995 var eina árið par sem orðalag spurningarinnar var örlítið öðruvísi en hin árin, en pá var spurningin orðuð pannig „Finnst pér að núverandi ríkisstjórn ætti að leggja mikla, nokkra eða litla áherslu á orkufreka stóriðju umfram fyrirliggjandi áform?"“

Megináhersla okkar er á kosningahegðun fólks og til að mæla hana notum við spurningu um hvaða flokk svarendur kusu í síðustu alpingiskosningum. Spurningin var óbreytt öll árin og var orðuð pannig „Hvaða flokk eða lista kaust pú?“ Aðeins peir sem höfðu pegar svarað pví að peir hefðu kosið í undangengnum alpingiskosningum voru spurðir pessarar spurningar. Aðrar bakgrunnsbreytur notaðar í greiningunni eru kyn, aldur, búseta, menntun, og tekjur. Upplýsingar um kyn, aldur og búsetu voru fengnar úr pjóðskrá Íslands. Búsetu er skipt upp í höfuðborgarsvæðið annars vegar og hins vegar landsbyggðir. Menntun svarenda tók prjú gildi eftir pví hvort peir hefðu lokið grunnskólanámi eða minna, framhaldsskólanámi eða háskólanámi. Spurt var um heildartekjur viðkomandi annars vegar og heildartekjur viðkomandi og maka samanlagt hins vegar. Tekjur voru flokkaðar í fimm jafn stóra fimmtunga par sem fyrsti fimmtungur stendur fyrir tekjubil fyrir lægstu tekjur og fimmti fimmtungur stendur fyrr tekjubil fyrir hæstu tekjur.

\section{3. Úrvinnsla}

Við úrvinnslu var notast við tölfræðiforritið SPSS. Tvíkosta aðhvarfsgreining var notuð til að kanna samband kyns, aldurs, búsetu, menntunar, tekna, stuðnings við stjórnmálaflokk og viðhorfa til umhverfismála og orkufrekrar stóriðju. Í greiningarferlinu var byrjað á að nota aðhvarfsgreiningu fyrir raðbreytur til að skoða samband bakgrunnspátta og viðhorfa til umhverfismála og stóriðju. Slíkt líkan var valið til að freista pess að ná peirri dreifingu sem 5 punkta kvarði býður upp á. Hins vegar kom í ljós að í nokkrum tilfellum uppfylltu líkönin ekki forsendu raðbreytuaðhvarfsgreiningar um hlutfallsleg líkindi. Pví var ákveðið að notast við tvíkosta aðhvarfsgreiningu. Tvíkosta aðhvarfsgreining var gerð fyrir hvora fylgibreytu um sig fyrir hvert ár. 
Fyrir tvíkosta aðhvarfsgreiningu voru fylgibreyturnar kóðaðar pannig að í breytu um umhverfismál, par sem spurt var hvort ríkisstjórnin ætti að taka umhverfismál fram yfir hagvöxt, fengu peir gildið 1 sem voru sammála („Alveg sammála“, og „Frekar sammála“) en gildið 0 fengu peir sem voru ósammála („Skiptir ekki máli““ „Frekar ósammála“ eða „Alveg ósammála“). Fylgibreyta um viðhorf til stóriðju, par sem spurt var hversu litla eða mikla áherslu viðkomandi vildi að ríkisstjórnin myndi leggja á orkufreka stóriðju, var kóðuð pannig að peir sem vildu láta leggja áherslu á stóriðju fengu gildið 1 („,Mjög mikla áherslu“ eða „Frekar mikla áherslu“) og peir sem vildu ekki láta leggja áherslu á stóriðju fengu gildið 0 („Hvorki mikla né litla“, „Frekar litla áherslu“ eða „Mjög litla eða enga áherslu'v).

Í tvíkosta aðhvarfsgreiningu voru frumbreytur kóðaðar pannig að karlar fengu gildið 0 og konur 1 á breytunni kyn, höfuðborgarsvæðið fékk gildið 0 og landsbyggðirnar gildið 1 á búsetubreytunni, peir sem einungis hafa lokið grunnskólaprófi eða minna voru valdir sem viðmiðunarhópur fyrir menntunarbreytuna og svör peirra sem lokið hafa framhaldsskólaprófi annars vegar og háskólaprófi hins vegar borin saman við viðmiðunarhópinn. Sama gildir fyrir tekjur, p.e. fyrsti fimmtungur var valinn sem viðmiðunarhópur fyrir annan fimmtung tekna, priðja fimmtung og svo framvegis.

Áhrifakóðun var notuð til að kóða breytuna sem segir til um stuðning við stjórnmálaflokk par sem flokkum voru gefin gildin 0,1 og -1. Fyrir hvern stjórnmálaflokk var búin til ein breyta nema fyrir „Kaus ekki/ skilaði auðu“ sem var viðmiðunargildi allra stjórnmálaflokka og tók ávalt gildið -1. Pannig tók breyta fyrir Vinstrihreyfinguna - grænt framboð gildið 1, annar kaus ekki/skilaði auðu tók gildið -1 meðan aðrir stjórnmálaflokkar fengu gildið 0. Pannig gekk kóðunin fyrir hvern stjórnmálaflokk fyrir sig koll af kolli. Pegar áhrifakóðun er beitt má túlka líkindahlutfall eins stjórnmálaflokks sem frávik frá óvegnu meðaltali allra stjórnmálaflokkanna. Pannig má t.d. túlka stuðulinn fyrir Vinstrihreyfinguna - grænt framboð pannig að hann segi til um mun á viðhorfi kjósenda VG og almennu viðhorfi allra kjósenda pað árið, í stað pess að vera bundin af pví að skoða frávik frá einum stjórnmálaflokki ef staðgengilskóðun hefði verið beitt. Niðurstöður par sem gefið er upp öryggisbil allra breytna í töflu 3 og 4 má finna í viðaukatöflu 1 og viðaukatöflu 2.

Við greiningu á viðhorfum svarenda út frá pví hvaða flokk peir studdu í alpingiskosningum eru sýndir peir flokkar sem buðu fram til kosninga árið 2017. Pó var Alpýðuflokknum og Alpýðubandalaginu haldið inni með pví að fella pá saman við aðra stjórnmálaflokka, annars vegar Samfylkingu og hins vegar Vinstrihreyfinguna - grænt framboð. Pessir tveir flokkar buðu í fyrsta skipti fram í Alpingiskosningunum árið 1999 og pví endurspeglar kosningahegðun fyrir pann tíma stuðning Alpýðuflokk annars vegar (Samfylking) og Alpýðubandalag hins vegar (Vinstrihreyfingin - grænt framboð).

\section{Niðurstöður}

\subsection{Hafa viðhorf Íslendinga til umhverfismála, hagvaxtar og orkufrekrar stóriðju breyst á 30 árum?}

Fyrsta spurning okkar er hvernig viðhorf á Íslandi hafa breyst og hvort pau tengist staðbundnum málefnum. Mynd 1 sýnir að frá árinu 1987 til 2017 er hlutfall peirra sem 
Sóllilja Bjarnadóttir, Inga Rún Sæmundsdóttir,

Sigrún Ólafsdóttir, Porvarđur Árnason og

Guđbjörg Andrea Jónsdóttir
STJÓRNMÁL

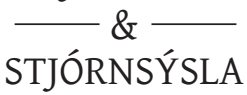

eru sammála pví að aðgerðir í umhverfismálum eigi að hafa forgang fram yfir aukinn hagvöxt ávallt hærra en hlutfall peirra sem vilja leggja áherslu á aukinn hagvöxt fram yfir umhverfismál, að undanskildu árinu 2009. •ó að áhersla á umhverfismál hafi ekki verið eins mikil 1987 og undanfarin ár, voru pað engu að síður um 50\% sem völdu aðgerðir í umhverfismálum umfram hagvöxt, en um 30\% völdu hagvöxt pað ár. Svipaðar tölur má sjá árið 1991 en árið 1995 dregur aðeins saman með svarendum. Munurinn eykst svo aftur árið 1999, minnkar 2003 en eykst árið 2007. Markverðustu niðurstöðurnar birtast síðan árið 2009, í kjölfar kosninga sem voru bein afleiðing Hrunsins og búsáhaldabyltingarinnar, en pá fer hlutfall peirra sem vilja auka hagvöxt (um 50\%) yfir hlutfall peirra sem velja aðgerðir í umhverfismálum (ríflega 30\%) í fyrsta og eina skiptið undanfarin 30 ár. Pessar niðurstöður koma ekki á óvart, par sem pjóðin hafði nýlega gengið í gegnum eitt mesta efnahagsáfall Íslandssögunnar og eitt af stærstu bankahrunum á heimsvísu með tilheyrandi atvinnuleysi. Рað sem gerist á næstu árum er pó jafn áhugavert, par sem áherslan færist hratt yfir á umhverfismálin eftir 2009, árið 2013 er pað svipað hlutfall sem velur pau og hagvöxt (45-50\%) en árið 2016 hafa aðgerðir í umhverfismálum tekið stökk, og pá velja tæp 70\% aðgerðir í umhverfismálum umfram hagvöxt og pað hlutfall hélst svipað í kosningunum árið eftir. Niðurstöður styðja pví tilgátu 1 par sem fjöldi peirra sem vildi leggja áherslu á hagvöxt umfram umhverfismál í kjölfar Hrunsins jókst, en hafa ber í huga að sú breyting varð skammlíf. Hlutfall peirra sem vildu leggja áherslu á umhverfismál fram yfir aukinn hagvöxt varð í kjölfar pessa hærra en nokkru sinni áður.

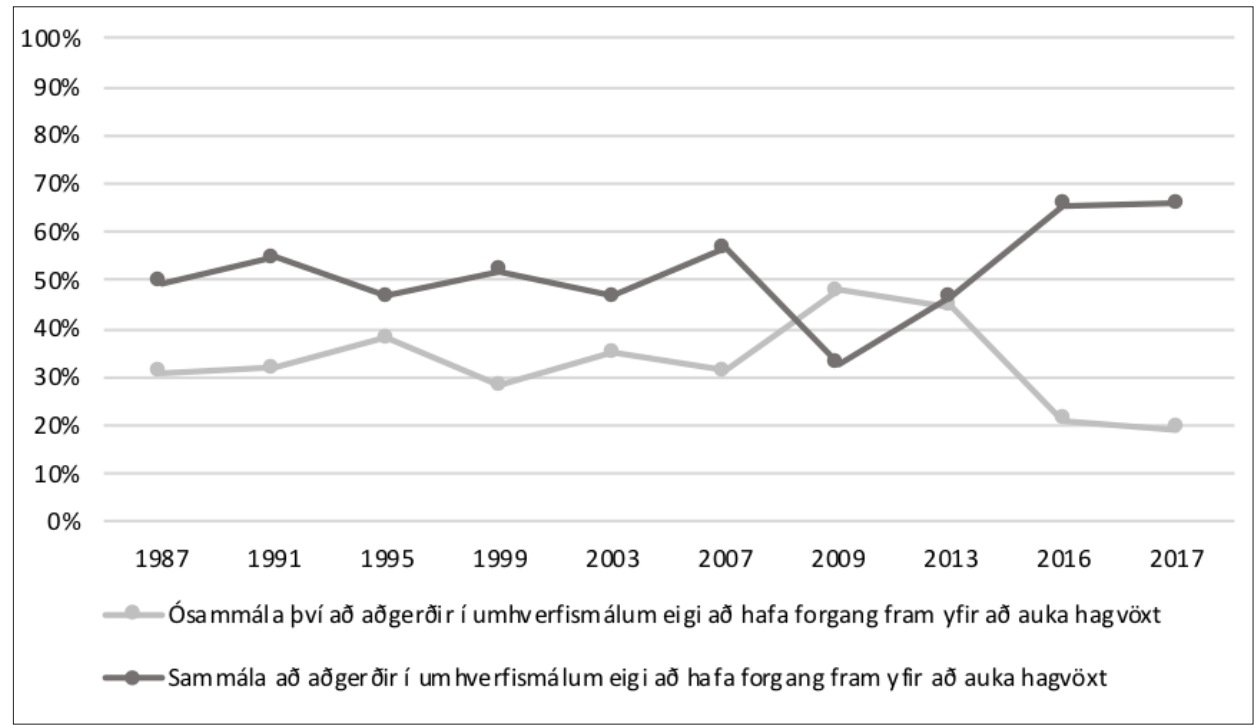

Mynd 1. Viðhorf Íslendinga til ađgerđa í umhverfismálum fram yfir hagvöxt á árunum 1987 til 2017

Í tilgátu tvö er spurt hvort að breytingar verða á viðhorfi fólks til stóriðju hér á landi yfir tíma, og pá sérstaklega litið til hvort og hvernig breytingarnar eiga sér stað í kringum 
opnum Kárahnjúkavirkjunar árið 2007. Mynd 2 sýnir skýrar breytingar á árunum 1991 til 2017, en síðan 1995 hefur hlutfall peirra sem eru ósammála pví að leggja áherslu á orkufreka stóriðju aukist ár frá ári og árið 2017 voru 80\% Íslendinga ósammála pví að leggja áherslu á stóriðju. Pegar niðurstöðurnar eru skoðaðar yfir tímabilið sést að um helmingur var ósammála pví árið 1991, en hlutfallið fer niður í 30\% árið 1995, eykst í 40\% árið 1999 og minnkar lítillega árið 2003. Sérstaklega athyglisvert er að sjá að árið 2007, eftir opnun Kárahnjúkavirkjunar, sést stórt stökk par sem 60\% eru ósammála pví að leggja áherslu á stóriðju og um pað bil 14\% sammála. Petta er mesti munur sem hafði sést fram að peim tíma sem hér er til skoðunar. En líkt og með meiri áherslu á hagvöxt í kjölfar Hrunsins, sjáum við aukna áherslu á stóriðju árið 2009 en pá voru rétt undir 50\% ósammála slíkri áherslu. Síðan pá hefur andstaða við stóriðju aukist, hlutfall peirra sem eru ósammála er aftur komið í 60\% árið 2013, en um 80\% bæði 2016 og 2017. Tilgáta 2 er pví studd par sem sífellt færri vilja leggja áherslu á stóriðju yfir tíma. Einnig sést að eftir opnun Kárahnjúkavirkjunar jókst fjöldi peirra sem var ósammála pví að leggja aukna áherslu á orkufreka stóriðju töluvert.

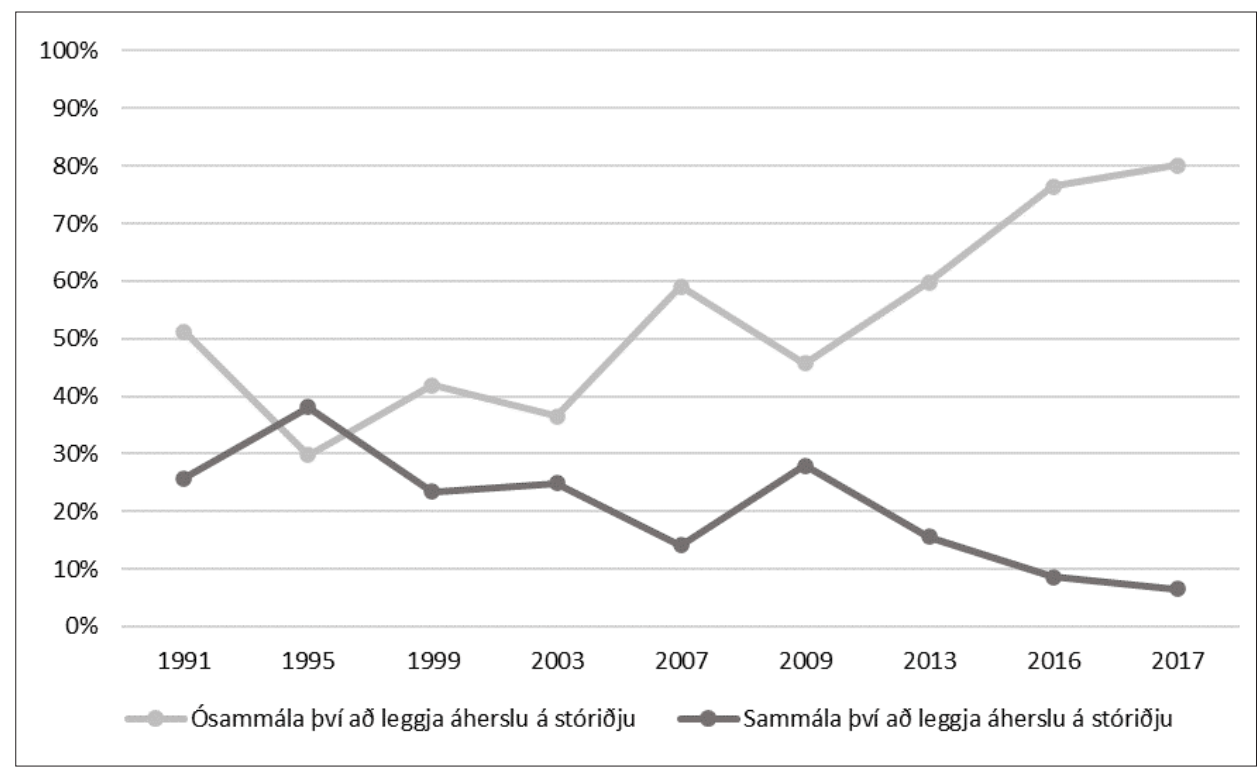

Mynd 2. Viðhorf Íslendinga til orkufrekrar stóriðju á árunum 1991 til 2017

\subsection{Hver er munurinn á viðhorfum kjósenda mismunandi stjórnmálaflokka til umhverfismála, hagvaxtar og orkufrekrar stóriðju?}

Seinni rannsóknarspurningin snérist um að skoða hvort tenging væri á milli viðhorfa og kosningahegðunar Íslendinga. Í tilgátu 3 er kannað hvort kjósendur flokka sem eru lengra til vinstri séu líklegri til pess að velja umhverfismál fram yfir hagvöxt miðað við pá sem eru staðsettir hægra megin sem séu svo líklegri til að velja hagvöxt fram yfir um- 


\section{STJÓRNMÁL

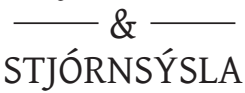

hverfismál. Tafla 3 sýnir niðurstöður tvíkosta aðhvarfsgreiningar sem kannar sambandið milli kosningahegðunar og pess hvort fólk velji umhverfismál fram yfir hagvöxt eða öfugt, par sem stýribreytur eru kyn, aldur, búseta, menntun og tekjur. Sýnt er líkindahlutfall sem má túlka pannig að ef talan er lægri en 1 pá er hópurinn líklegri til að velja hagvöxt fram yfir aðgerðir í umhverfismálum en ef hún er hærri en 1 pá er hópurinn líklegri til að velja aðgerðir í umhverfismálum fram yfir hagvöxt. Viðaukatafla 3 sýnir fjölda svarenda í aðhvarfsgreiningunni og fjölda brottfallsgilda (peir sem segja ,,veit ekki“, ,,vil ekki svara" eða fengu ekki spurningu).

Niðurstöðurnar sýna að stjórnmálaviðhorf eru eina breytan sem hefur marktæk áhrif á val öll árin. Kynjamunur kemur aðeins fram prisvar sinnum yfir tímabilið, en árin 1991, 1999 og 2007 eru konur líklegri til að leggja áherslu á aðgerðir í umhverfismálum en karlar. Aldur var marktækur árin 1995, 2003 og 2009, en pá lögðu peir eldri frekar áherslu á hagvöxt heldur en peir sem yngri eru. Árin 2003 og 2009 leggur fólk á landsbyggðunum síður áherslu á aðgerðir í umhverfismálum miðað við fólk á höfuðborgarsvæðinu. Menntun hefur engin áhrif nema árið 2009 par sem fólk með háskólapróf var líklegra til að leggja áherslu á aðgerðir í umhverfismálum, samanborið við pá sem eru með grunnskólapróf. Tekjur hafa lítil áhrif en áhugavert er að skoða að árið 2009 (rétt eftir Hrunið) eru pað frekar hinir efnameiri en peir efnaminni sem velja hagvöxt umfram aðgerðir í umhverfismálum.

Hvað stjórnmálaflokkana varðar pá sést að Vinstrihreyfingin - grænt framboð (VG) og Sjálfstæðisflokkurinn eru einu stjórnmálaflokkarnir sem hafa marktæk frávik frá almennu viðhorfi öll árin. Đar sést að stuðningsfólk VG er líklegra en aðrir til pess að velja umhverfismál fram yfir hagvöxt öll árin og vex áherslan á umhverfismál fram yfir hagvöxt jafnt og pétt frá árinu 1991 og nær hámarki árið 2007, par sem stuðningsfólk VG er fjórum sinnum líklegri til pess að styðja umhverfismál fram yfir hagvöxt en aðrir kjósendur pað árið. Kjósendur Sjálfstæðisflokksins eru líklegri til pess að velja hagvöxt umfram umhverfismál allt tímabilið. Niðurstöður fyrir kjósendur Samfylkingarinnar breytast milli ára par sem peir velja hagvöxt fram yfir umhverfismál árið 1995 en sýna svo meiri stuðning við umhverfismál árin 1999, 2007 og 2013. Kjósendur Framsóknarflokksins taka hagvöxt fram yfir umhverfismál árin 2003 til 2013 og svo aftur árið 2017. Раð sama má sjá hjá kjósendum Miðflokksins sem taka hagvöxt fram yfir umhverfismál árið 2017. Árið 2016 sést að kjósendur Pírata leggja áherslu á umhverfismál fram yfir hagvöxt. Ekki er samband milli pess að kjósa Viðreisn eða Flokk fólksins og að taka afstöðu til annaðhvort umhverfismála eða hagvaxtar. Að lokum má sjá að árin 1991, 1995 og 2013 eru aðrir flokkar hlynntari pví að taka umhverfismál fram yfir hagvöxt en árið 1999 kemur fram hið andstæða, p.e. að kjósendur annarra flokka taka hagvöxt fram yfir umhverfismál. Pví er tilgáta 3 studd, sem gerir ráð fyrir að kjósendur flokka sem eru lengra til vinstri á pólitískum skala séu líklegri til pess að velja umhverfi fram yfir hagvöxt en peir sem eru staðsettir hægra megin á pólitískum skala sem séu svo líklegri til að velja hagvöxt fram yfir umhverfi. 
Tafla 3. Tvíkosta ađ̆hvarfsgreining sem sýnir hversu ósammála eđa sammála fólk er pví að taka umhverfismál fram yfir hagvöxt greint út frá stuðningi við stjórnmálaflokk fyrir hvert ár. Gefið er upp líkindahlutfall (e. odds ratio) og marktekt.

\begin{tabular}{|c|c|c|c|c|c|c|c|c|c|}
\hline & $\begin{array}{c}1991 \\
\text { OR }\end{array}$ & $\begin{array}{c}1995 \\
\text { OR }\end{array}$ & $\begin{array}{c}1999 \\
\text { OR }\end{array}$ & $\begin{array}{c}2003 \\
\text { OR }\end{array}$ & $\begin{array}{c}2007 \\
\text { OR }\end{array}$ & $\begin{array}{c}2009 \\
\text { OR }\end{array}$ & $\begin{array}{c}2013 \\
\text { OR }\end{array}$ & $\begin{array}{c}2016 \\
\text { OR }\end{array}$ & $\begin{array}{c}2017 \\
\text { OR }\end{array}$ \\
\hline \multicolumn{10}{|l|}{ Skurðpunktur } \\
\hline & 0,97 & 0,70 & $0,58^{*}$ & 0,80 & 1,48 & $0,33^{* * *}$ & 1,63 & 1,65 & $2,66^{* *}$ \\
\hline \multicolumn{10}{|l|}{ Kyn } \\
\hline \multicolumn{10}{|l|}{ Karl (viðmiðunarbreyta) } \\
\hline Kona & $1,39^{*}$ & 1,24 & $2,14^{* * *}$ & 1,11 & $1,47^{* *}$ & 1,23 & 1,03 & 1,16 & 1,13 \\
\hline \multicolumn{10}{|l|}{ Aldur } \\
\hline Alduríárum & 1,00 & $1,01^{*}$ & 1,00 & $1,01^{* *}$ & 1,00 & $1,01^{* *}$ & 1,00 & 1,01 & 1,00 \\
\hline \multicolumn{10}{|l|}{ Búseta } \\
\hline \multicolumn{10}{|c|}{ Höfuðborg (viðmiðunarbreyta) } \\
\hline Landsbyggð & 0,93 & 1,09 & 0,83 & $0,70^{*}$ & 1,12 & $0,62^{* *}$ & 0,78 & 0,86 & 0,60 \\
\hline \multicolumn{10}{|l|}{ Menntun } \\
\hline \multicolumn{10}{|c|}{ Grunnskólapróf (viðmiðunarbreyta) } \\
\hline Framhaldsskólapróf & 1,24 & 1,16 & 1,18 & 1,04 & 0,88 & 1,18 & 1,25 & 1,18 & 0,53 \\
\hline Háskólapróf & 1,06 & 1,04 & 1,34 & 1,19 & 1,17 & $1,60^{*}$ & 1,25 & 1,44 & 0,81 \\
\hline \multicolumn{10}{|l|}{ Mánaðartekjur } \\
\hline \multicolumn{10}{|c|}{ Fyrsti fimmtungur (viðmiðunarbreyta) } \\
\hline Annar fimmtungur & 1,24 & 0,86 & 1,27 & 0,75 & 0,89 & $0,63^{*}$ & 1,01 & 0,86 & 0,37 \\
\hline priðji fimmtungur & 1,06 & $0,57^{* *}$ & 1,01 & 1,05 & 0,88 & $0,56^{* *}$ & 0,90 & 1,00 & 0,50 \\
\hline Fjórđi fimmtungur & 1,03 & 0,80 & 1,29 & 0,71 & 0,97 & $0,52^{*}$ & $0,61^{*}$ & 0,87 & 0,54 \\
\hline Fimmti fimmtungur & 1,02 & 0,73 & 1,28 & $0,49^{* *}$ & 0,80 & $0,53^{*}$ & $0,40^{* * *}$ & $0,48^{* *}$ & 0,51 \\
\hline \multicolumn{10}{|c|}{ Stuðningur við stjórnmálaflokk } \\
\hline \multicolumn{10}{|c|}{ Kaus ekki/skilađi auðu (viðmiðunarbreyta) } \\
\hline VG & $2,01^{* * *}$ & $1,67^{* *}$ & $2,39^{* * *}$ & $4,23^{* * *}$ & $4,00^{* * *}$ & $3,19^{* * *}$ & $4,23^{* * *}$ & $1,67^{*}$ & $2,00^{* *}$ \\
\hline Samfylkingin & 0,83 & $0,62^{* *}$ & $1,43^{*}$ & 1,08 & $1,33^{*}$ & 0,92 & $1,54^{*}$ & 1,83 & 1,36 \\
\hline Framsóknarflokkurinn & 0,91 & 0,85 & 0,79 & $0,55^{* * *}$ & $0,36^{* * *}$ & $0,58^{* *}$ & $0,51^{* * *}$ & 0,66 & $0,60^{*}$ \\
\hline Sjálfstæđisflokkurinn & $0,48^{* * *}$ & $0,78^{* *}$ & $0,66^{* * *}$ & $0,51^{* * *}$ & $0,43^{* * *}$ & $0,51^{* * *}$ & $0,31^{* * *}$ & $0,47^{* * *}$ & $0,49^{* * *}$ \\
\hline Píratar & & & & & & & 1,00 & $1,94^{* *}$ & 1,99 \\
\hline Viđreisn & & & & & & & & 1,01 & 1,02 \\
\hline Flokkur fólksins & & & & & & & & & 0,64 \\
\hline Miðflokkurinn & & & & & & & & & $0,48^{*}$ \\
\hline Ađrir flokkar & $1,79^{* *}$ & $1,56^{* *}$ & $0,50^{*}$ & 1,05 & 1,17 & 1,18 & $1,56^{* *}$ & 1,14 & 1,28 \\
\hline Fjöldi & $\mathrm{N}=952$ & $\mathrm{~N}=1152$ & $N=969$ & $\mathrm{~N}=818$ & $\mathrm{~N}=980$ & $\mathrm{~N}=885$ & $N=894$ & $\mathrm{~N}=741$ & $\mathrm{~N}=682$ \\
\hline Cox \& Snell $\mathrm{R}^{2}$ & 0,07 & 0,04 & 0,09 & 0,10 & 0,14 & 0,11 & 0,17 & 0,09 & 0,09 \\
\hline Nagelkerke $\mathrm{R}^{2}$ & 0,09 & 0,05 & 0,12 & 0,14 & 0,19 & 0,16 & 0,23 & 0,13 & 0,13 \\
\hline
\end{tabular}

Fjórða tilgátan prófar hvort kjósendur flokka sem eru staðsettir til vinstri séu ólíklegri til pess að leggja aukna áherslu á orkufreka stóriðju en peir sem eru staðsettir hægra megin. Í töflu 4 má sjá niðurstöður tvíkosta aðhvarfsgreiningar par sem kannað er hvort kjósendur eru sammála eða ósammála pví að ríkisstjórnin eigi að leggja áherslu á orkufreka stóriðju par sem stýribreytur eru kyn, aldur, búseta menntun og tekjur. Aftur eru niðurstöðurnar sýndar sem líkindahlutfall, par sem tala yfir 1 pýðir að hópurinn er líklegri til að leggja áherslu á stóriðju en undir 1 pýðir að hópurinn sé síður líklegur til að gera pað.

Konur eru ólíklegri til að styðja orkufreka stóriðju en karlar árin 1991 til 2013. Aldur 
kemur fram sem áhrifapáttur árin 2013 og 2017, en pá eru yngri kjósendur síður líklegri til að styðja stóriðju en peir sem eldri eru. Á árunum 1999, 2009 og 2013 verða íbúar á höfuðborgarsvæðinu ólíklegri til að vilja leggja áherslu á stóriðju en íbúar á landsbyggðinni. Nokkuð stöðugt samband hefur veriðá milli menntunar og viðhorfa til stóriðju, en frá árunum 1995 til 2016 hafa peir sem hafa háskólapróf verið síður líklegir til að styðja stóriðju, samanborið við pá sem hafa grunnskólapróf. Lítið samband virðist vera á milli tekna og við horfa til stóriðju, nema eitthvað samband árin 1995, 2009 og 2013. Par kemur fram að hinir efnameiri styðja frekar stóriðju en hinir efnaminni.

Niðurstöður stjórnmálaflokkanna sýna að Sjálfstæðisflokkurinn er eini flokkurinn sem hefur marktækt jákvæðari viðhorf til stóriðju yfir allt tímabilið en kjósendur almennt. Kjósendur Sjálfstæðisflokksins eru flest árin u.p.b. tvisvar til prisvar sinnum líklegri en kjósendur almennt til að leggja áherslu á stóriðju. Kjósendur VG eru ólíklegri til að leggja áherslu á stóriðju öll árin nema 2016 og 2017. Kjósendur Samfylkingarinnar eru einungis hlynntir stóriðju árið 1991. Kjósendur Framsóknarflokksins eru hlynntir pví að ríkisstjórnin ætti að leggja aukna áherslu á stóriðju árin 1999 til 2013. Afstaða kjósenda annarra flokka sem komu nýir á ping árið 2013 eða seinna til stóriðju er sambærileg við almenn viðhorf kjósenda. Kjósendur annarra flokka eru hlynntari pví að leggja ekki áherslu á stóriðju árin 1991 til 1999 og svo aftur árin 2013 til 2016. 
Tafla 4. Tvíkosta aðhvarfsgreining sem sýnir hvort ríkisstjórnin ætti að leggja litla (enga) áherslu á stóriðju eđa leggja áherslu á stóriðju greint út stuđningi við stjórnmálaflokk fyrir hvert ár. Gefið er upp líkindahlutfall (e. odds ratio) og marktekt.

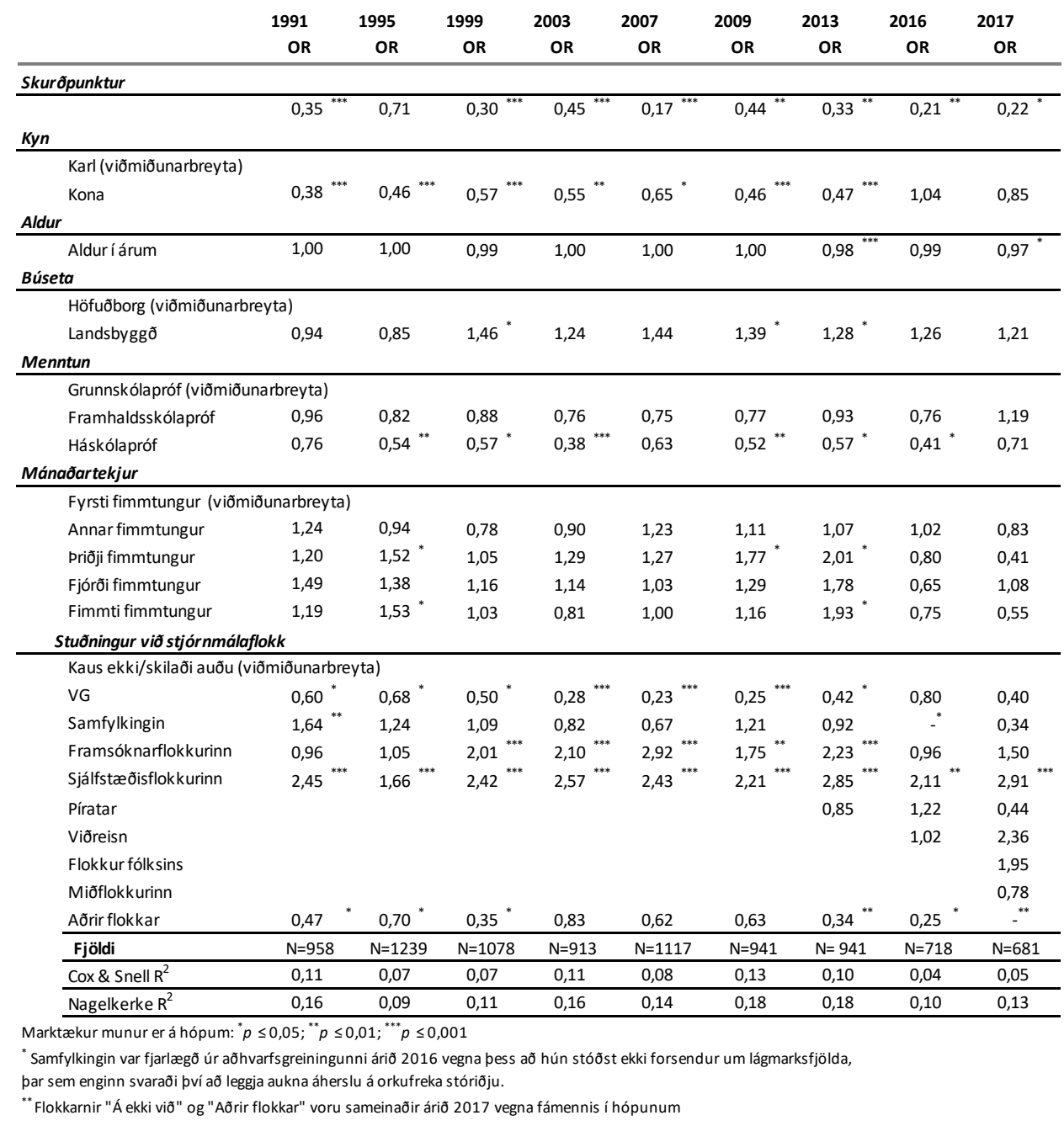

\subsection{Hver eru áhrif íslenskra stjórnmála á viðhorfin?}

Dar sem flokkapólitík hefur sterkt samband við viðhorf til umhverfismála og stóriðju ásamt pví að um er að ræða málefni sem ágreiningur hefur verið um 1 íslenskum stjórnmálum skoðum við sérstaklega viðhorf kjósenda allra flokka á Alpingi árið 2020 til pessara tveggja spurninga á peim tímapunktum sem við á. Myndir 3 og 4 sýna hvernig 


\section{STJÓRNMÁL \& STJÓRNSÝSLA}

viðhorf kjósenda stjórnmálaflokkanna breytast milli ára í takt við pær samfélagslegu breytingar sem áttu sér stað á hverju kjörtímabili sem til skoðunar er. Flokkar sem sýndir eru á myndunum eru Flokkur fólksins, Framsókn, Miðflokkurinn, Píratar, Samfylkingin, Sjálfstæðisflokkurinn, Viðreisn og Vinstrihreyfingin - grænt framboð. Par sem spurt hefur verið um viðhorf til pess að forgangsraða umhverfismálum fram yfir hagvöxt frá árinu 1987 sýnum við breytingar á viðhorfum frá pessum tímapunkti.

Mynd 3 sýnir að hlutfall peirra sem velja aðgerðir í umhverfismálum fram yfir hagvöxt er hæst hjá VG og lægst hjá kjósendum Framsóknar og Sjálfstæðisflokks. Nokkur munur var á kjósendum VG og Samfylkingar til ársins 2016 en pá hefur nánast dregið saman með flokkunum og um 80\% kjósenda beggja flokka leggja áherslu á umhverfismál fremur en hagvöxt. Einnig sést greinilega að í kjölfar Hrunsins árið 2009 minnkaði hlutfall peirra sem völdu aðgerðir í umhverfismálum fram yfir hagvöxt mikið, en fór pó ekki undir 50\% hjá VG. Hjá Samfylkingu fór pað hins vegar niður í 30\% og einungis um 20\% kjósenda Framsóknar og Sjálfstæðisflokks völdu umhverfismál yfir hagvöxt. Ef litið er á flokkana yfir tíma pá hefur stuðningur við umhverfismál fram yfir hagvöxt á meðal kjósenda VG verið á bilinu 50\% til rúmlega 90\%, Samfylkingar frá 30\% til tæplega 80\%, Framsóknar frá 20\% til rúmlega 50\% og svipað hjá Sjálfstæðisflokki. Pegar skoðaðir eru flokkarnir sem hafa komið til sögunnar síðan 2013, pá er greinilegt að kjósendur Pírata hafa svipaða afstöðu og VG og Samfylking hvað pessi viðhorf varðar en Flokkur Fólksins sýnir heldur minni stuðning við umhverfismálin en Samfylkingin. Баð eru pó kjósendur Miðflokksins sem skera sig úr; árið 2017 er hann eini flokkurinn par sem stuðningur er undir 50\%, en pað ár völdu um 45\% kjósenda Miðflokksins aðgerðir í umhverfismálum fram yfir hagvöxt. Pegar farið er yfir landslagið árið 2017 pá virðast vera tvær fylkingar, annars vegar VG, Píratar, Samfylking og Flokkur Fólksins og hins vegar Framsókn, Sjálfstæðisflokkur og Miðflokkur. Viðreisn er pó undanskilin pessum tveimur fylkingum par sem flokkurinn raðar sér mitt á milli pessara tveggja hópa. 


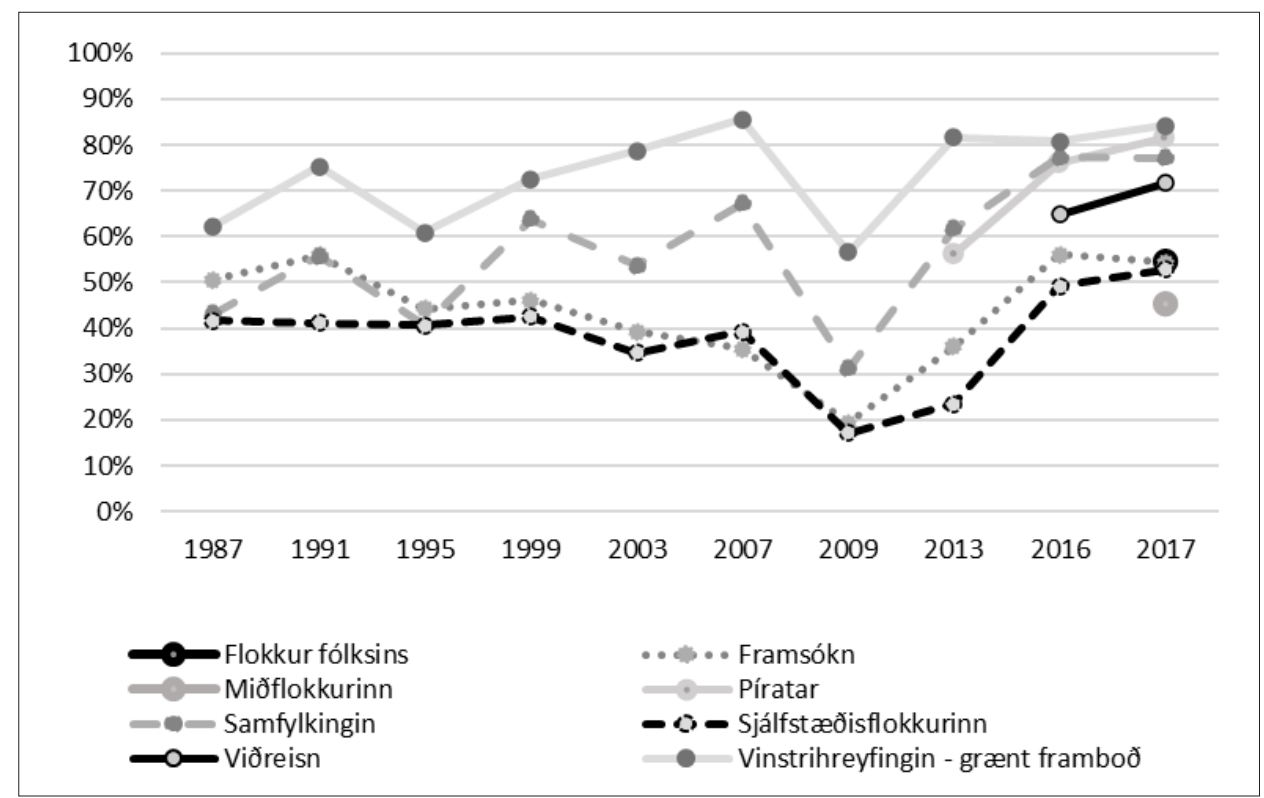

Mynd 3. Hlutfall peirra sem eru sammála bví ađ á næstu árum ættu ađgerđir í umhverfismálum að hafa forgang fram yfir tilraunir til ađ auka hagvöxt sýnt eftir hvađa flokk viðkomandi kaus árin 1987-2017

Spurt hefur verið um viðhorf til stóriðju síðan 1991 og má sjá niðurstöður eftir kjósendum flokkanna á mynd 4. Fljótt á litið sést að mikil samstaða hafi nú náðst á meðal almennings um málefni sem greinilega var töluvert ágreiningsefni við upphaf mælinganna. Ef skoðuð eru viðhorf kjósenda flokkanna fjögurra sem eru með gögn allt tímabilið, pá er verulegur munur árið 1991, en pá vildu um 40\% kjósenda Sjálfstæðisflokks sjá aukna áherslu á stóriðju, um 22\% kjósenda Framsóknar, ríflega 30\% kjósenda Samfylkingar og 14\% kjósenda VG. Munurinn milli flokka helst nokkuð stöðugur fram til 2016 en pá hefur dregið verulega saman. Áhugavert er pó að í kjölfar Hrunsins virðast kjósendur Framsóknar og Sjálfstæðisflokks hafa verulega trú á stóriðju sem leið út úr Hruninu en pað á ekki við um kjósendur VG en innan við 10\% kjósenda peirra hafa viljað sjá aukna áherslu á stóriðju allar götur síðan 1999. Í kringum framkvæmd og opnun Kárahnjúkavirkjunar má sjá að hlutfall peirra sem eru sammála pví að leggja aukna áherslu á orkufreka stóriðju lækkar meðal allra flokka. Einnig sést að árið 2007 var nánast enginn munur á kjósendum Samfylkingar og VG en stuðningur við stóriðju jókst meðal kjósenda Samfylkingar í kjölfar Hrunsins. Árið 2017 er lítill munur á flokkunum hvort sem um er að ræða gamla fjórflokkinn eða nýrri flokka. Đað ár mælist stuðningur meðal kjósenda Sjálfstæðisflokksins mestur en pó eru pað einungis rúmlega 10\% kjósenda hans sem vilja aukna áherslu á stóriðju. Kjósendur allra annarra flokka raða sér fyrir neðan pað. 


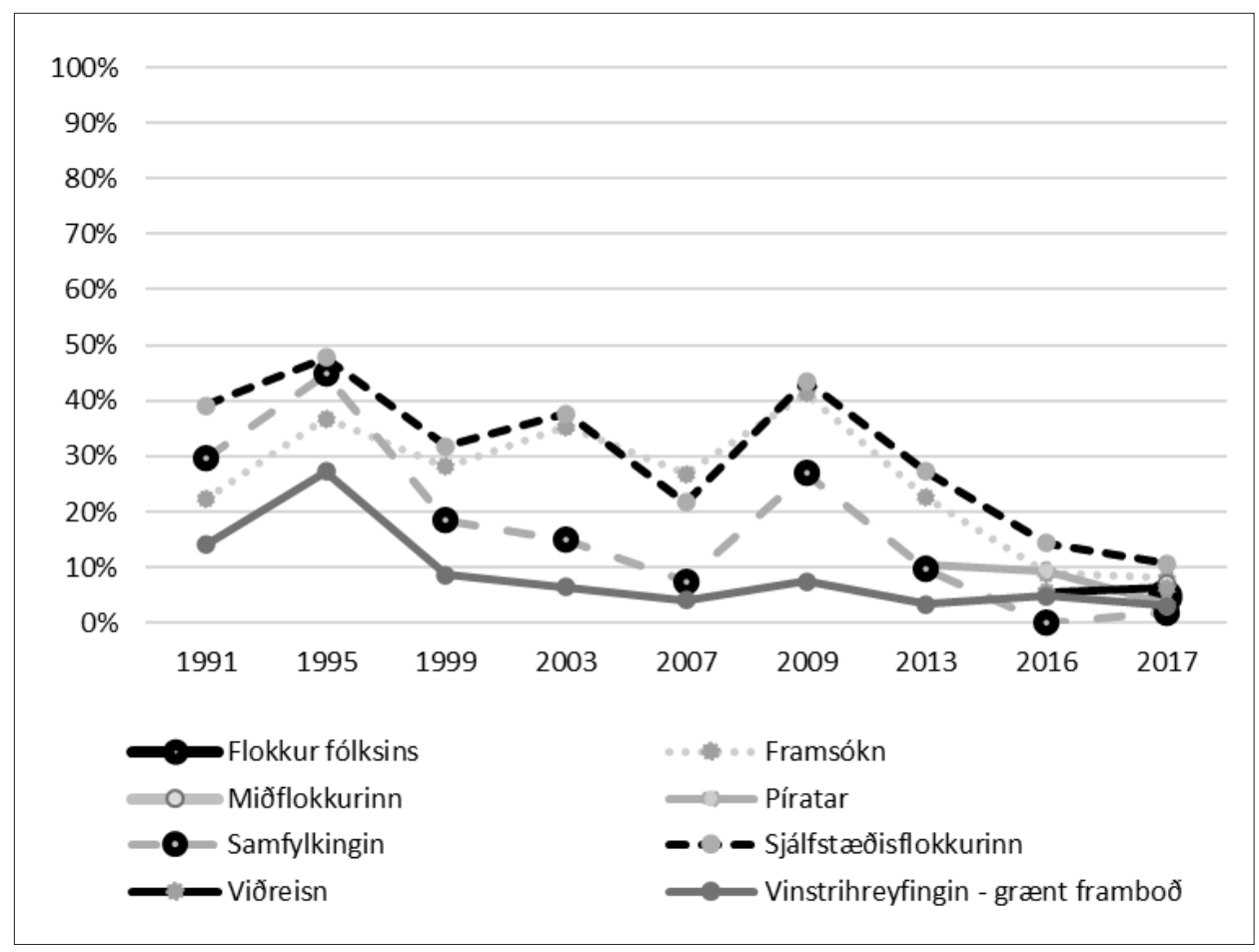

Mynd 4. Hlutfall peirra sem vilja leggja aukna áherslu á orkufreka stóriđju út frá hvađa flokk viðkomandi kaus árin 1991-2017

\section{Umræða}

Í pessari grein var skoðað hvort og pá hvernig viðhorf almennings til umhverfismála og stóriðju hafa breyst samhliða pólitískum og efnahagslegum áherslubreytingum á síðustu áratugum. Fjallað var um pær viðhorfsbreytingar sem hafa orðið á 30 ára tímabili og pá sérstaklega möguleg áhrif Hrunsins á viðhorf einstaklinga til umhverfismála og hagvaxtar sem og hvort að sjá mætti breytingar á viðhorfum til orkufrekrar stóriðju í kringum opnun Kárahnjúkavirkjunar. Í framhaldi af pví var einnig skoðað hvort afstaða fólks í pessum málefnum tengdist pví hvaða flokk fólk kaus.

Til að svara fyrstu rannsóknarspurningunni, sem kannaði hvort viðhorfsbreytingar hafi orðið yfir tíma sem og hvort staðbundin málefni á Íslandi hafi haft áhrif á viðhorf einstaklinga, pá virtist vera mikil áhersla á umhverfismál hjá Íslendingum nánast allt tímabilið. Бó að áhersla á umhverfismál hafi ekki verið nærri eins mikil árið 1987 og undanfarin ár, voru pað engu að síður um 50\% kjósenda sem völdu aðgerðir í umhverfismálum umfram hagvöxt. Samt sem áður voru nokkrar sveiflur á viðhorfum og mætti par helst nefna sveifluna sem varð árið 2009, en pað var eina skiptið á pessu 30 ára tímabili sem fjöldi peirra sem vildu leggja áherslu á umhverfsmál fram yfir hagvöxt lækkaði i öllum flokkum. Má pví sjá ákveðið mynstur par sem Íslendingar almennt vilja leggja áherslu á umhverfismál fram yfir hagvöxt, að undanskildu árinu 2009 par sem hagvöxtur 
var settur í forgang, væntanlega í kjölfar Hrunsins. Hins vegar má sjá að ef borin eru saman viðhorf til umhverfismála frá árinu 1987 og 2017 er tæplega 20\% heildaraukning á peim sem eru sammála peirri fullyrðingu að umhverfismál ættu að vera í forgangi fram yfir hagvöxt. Pessa aukningu mætti útskýra með kenningu Inglehart (1990) par sem pað virðast vera póstmódernísku gildin sem fylgja próun samfélaga sem hafi breytt viðhorfinu til umhverfismála yfir tíma. Eins og Inglehart nefnir pá skapast vandinn pegar stjórnvöld neyðast til að velja á milli umhverfisverndar og hagvaxtar og leiðir pað til pess að umhverfismál verði að „,pólitísku viðfangsefni“ (Inglehart 1995, 59). Рað gerðist hér á landi í kringum deilurnar um Kárahnjúkavirkjun en pá varð umhverfisvernd á stuttum tíma pólitískt viðfangsefni, en pví hefur verið haldið fram að við byggingu hennar hafi orðið grundvallarbreyting í umhverfisvernd hér á landi (Ólafur P. Hardarson \& Gunnar Helgi Kristinsson 2003; Jón Ólafsson 2006).

Enn fremur er hægt að styðja hugmyndir Inglehart (1990) um póstmódernísku gildin pegar skoðað er hversu miklu færri vilja leggja áherslu á stóriðju í dag samanborið við árið 1987. En 80\% voru ósammála pví að leggja ætti áherslu á stóriðju árið 2017 og sýnir pað að pó pað gæti fylgt hagvöxtur af stóriðjuframkvæmdum eru önnur gildi sem hafa meira vægi í dag. Í dag mætti færa rök fyrir pví að umhverfismál, meðal annars náttúruvernd, sé orðið meira pólitískt viðfangsefni en áður en ítarlegri rannsóknir á pví eru nauðsynlegar til að alhæfa um slíkt. Skilin á milli viðhorfa til umhverfismála og hagvaxtar sáust skýrt í gögnunum okkar beint í kjölfar Hrunsins. Eins og búist var við lagði hærra hlutfall svarenda áherslu á hagvöxt fram yfir umhverfismál en árin á undan, en par hefur slæm fjárhagsstaða landsins væntanlega spilað stórt hlutverk. Erlendar rannsóknir hafa sýnt að forgangsröðun almennings getur breyst í kjölfar efnhagshruns par sem einstaklingar virðast leggja meiri áherslu á hagvöxt fram yfir umhverfi (Kenny 2020), en pessi áherslubreyting var pó fljót að ganga til baka hér á landi. Gögnin okkar virðast undirstrika hvernig gildi einstaklinga innan samfélaga hafa próast í sömu hátt og Inglehart (1995) bendir á. Đó fleiri rannsóknir séu nauðsynlegar sem skoða petta samband er ljóst að almenningur hefur heilt yfir meiri tilhneigingu til að leggja áherslu á umhverfismál og er pað í takt við aukna umræðu um pað málefni í nútímasamfélagi.

Í annarri rannsóknarspurningunni var rýnt sérstaklega í viðhorf Íslendinga til umhverfismála, hagvaxtar og orkufrekrar stóriðju miðað við hvað viðkomandi kaus í síðustu kosningum. Niðurstöðurnar sýna að VG og Sjálfstæðisflokkurinn eru einu stjórnmálaflokkarnir sem hafa marktæk frávik frá almennu viðhorfi öll árin pegar skoðað er hvort einstaklingur sé líklegri til að velja umhverfi fram yfir hagvöxt. Par sem VG eru líklegri en aðrir til pess að velja umhverfismál fram yfir hagvöxt öll árin og kjósendur Sjálfstæðisflokksins líklegri til pess að velja hagvöxt umfram umhverfismál allt tímabilið. Almennt virðast síðan peir flokkar sem eru til vinstri oftar líklegri til að leggja áherslu á umhverfismál, mætti par t.d. nefna VG og Samfylkinguna. Kjósendur Framsóknarflokksins taka hagvöxt fram yfir umhverfismál árin 2003 til 2013 og svo aftur árið 2017. Píratar lögðu frekar áherslu á umhverfismál fram yfir hagvöxt árið 2016 á meðan Miðflokkurinn var líklegri til að leggja áherslu á hagvöxt umfram umhverfismál árið 2017. Ekki kom fram samband við kjósendur Viðreisnar og Flokk fólksins pegar skoðuð voru viðhorf peirra 


\section{STJÓRNMÁL

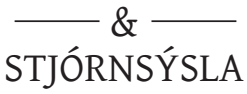

til pess að leggja frekar áherslu á hagvöxt fram yfir umhverfismál. Er petta í takt við aðrar rannsóknir, að peir sem eru til vinstri eru líklegri til að vilja fórna eigin tekjum til að vernda umhverfið (Sóllilja Bjarnadóttir 2020), eru meðvitaðri um umhverfisvandamál (Neymayer 2003), líklegri til að sampykkja hærri skatta í págu umhverfisverndar (Fairbrother 2017) og hafa meiri vilja til að koma í veg fyrir skemmdir á umhverfinu (Torgler \& García-Valiñas 2007). Sama mynstur má sjá í pessari rannsókn par sem VG og Samfylkingin hafa verið flokkaðir sem vinstri flokkar á meðan Sjálfstæðisflokkurinn hefur verið flokkaður sem hægri flokkur. Enn fremur mátti sjá að kjósendur Sjálfstæðisflokksins eru líklegri en aðrir kjósendur til að leggja áherslu á stóriðju öll árin og kjósendur VG ólíklegri en aðrir flokkar til að vilja leggja aukna áherslu á stóriðju, að undanskyldum árunum 2016 og 2017. Рað mætti pó útskýra með pví að á árunum 2016 og 2017 eru flestir stjórnmálaflokkar orðnir nokkuð samhljóma í bví að vilja ekki leggja áherslu á orkufreka stóriðju og pví sést ekki lengur sami munur á VG og öðrum stjórnmálaflokkum.

Í gögnunum úr ÍSKOS eru lagðar fram tvær spurningar, en hafa ber í huga að viðfangsefnið er flókið og margpætt og vísar bæði í staðbundnar og hnattrænar aðstæður. Spurningin um forgang umhverfismála eða hagvaxtar sver sig í ætt við ýmis mælitæki sem notuð hafa verið til að mæla umhverfishygð almennings á erlendum vettvangi. Mælingar á umhverfishygð hafa pó einnig notast við önnur mælitæki sem eru talsvert ólík pessari spurningu og pví er varasamt að alhæfa mikið út frá pessari einu spurningu. Jafnframt má gagnrýna orðalag pessarar tilteknu spurningar á peim forsendum að hún feli í sér „falska andstæðu“ á milli umhverfisverndar og hagvaxtar, samanber vaxandi umræðu um ,grænan hagvöxt“. Spurningin um áherslu stjórnvalda á stóriðju er sértækari; deilur um virkjanamál og stóriðju eru engan veginn séríslenskt fyrirbæri en hafa pó verið í miðpunkti náttúruverndarumræðunnar hérlendis um allmarga áratugi. Fólk getur verið fylgjandi eða andvígt uppbyggingu stóriðju af margvíslegum ástæðum og pví er engan veginn sjálfgefið að neikvæð viðhorf til stóriðju jafngildi jákvæðum viðhorfum til umhverfismála almennt. Ef horft er á niðurstöður beggja spurninga saman, gefa pær samt sem áđur skýra vísbendingu um almennt vaxandi vægi umhverfismála á Íslandi á undangengnum prjátíu árum. Hins vegar er ljóst að pað vantar hér á landi gögn til að skoða petta betur og draga lærdóm af. Með aukinni umhverfisvernd og breytingum í umhverfi okkar er nauðsynlegt að skilja ólíkar hliðar umhverfis- og auðlindamála til að geta fundið sem bestar lausnir við peim vandamálum sem við stöndum frammi fyrir.

Umræðan um umhverfismál er í mikilli deiglu um pessar mundir og hefur talsvert breyst á undanförnum 20 árum; stærsti hluti umræðunnar í dag er helgaður hnattrænum loftslagsbreytingum - hamfararhlýnun - en önnur eldri svið hafa nokkuð fallið í skuggann af henni. Ekki er sjálfgefið að breytingar í viðhorfum, sérstaklega til staðbundinna málaflokka eins og náttúruverndar eða virkjana og stóriðju, fylgi áfram sömu próun og verið hefur og gætu hnattrænar loftlagsbreytingar haft áhrif á pessa próun. Mikilvægt er að fylgjast áfram með peirri próun, með reglulegum og fjölpættum rannsóknum innan félagsvísinda. Aðrar rannsóknir á sviðinu gætu skoðað hvaða fleiri pættir á Íslandi hafa áhrif á pessar viðhorfsbreytingar. Pá skortir enn mikið upp á að hægt sé að svara ýmsum grundvallarspurningum um viðhorf Íslendinga til umhverfismála, t.d. hvort breytt við- 
horf tengist breytingum á gildismati, hvernig umhverfishygð tengist einstökum hefðbundnum áherslusviðum (svo sem náttúruvernd, landgræðslu eða skógrækt) og hvað ný áherslusvið í umræðunni (svo sem hamfararhlýnun) gæu leitt til í framtíðinni. Varla ætti pó að fara fram hjá neinum að umhverfismál eru komin til að vera í íslensku samfélagi og stjórnmálum. Með pessari grein freista höfundar pess að öðlast dýpri skilning á tengslum viðhorfa til umhverfistengdra málefna og stíga pannig skref 1 átt að bættari og heildstæðari skilningi á mikilvægi umhverfismála hérlendis.

\section{Aftanmálsgrein}

1 Upphaflegi textinn er á ensku, pýðing er höfunda: The issue was among the most fiercely debated in Icelandic politics, indicating the emergence of a new cleavage factor - environmental issues which only about five years earlier could be considered a minor issue in Icelandic politics. Close to 400 speeches on the bill (not counting committee meetings) in the Alpingi, where 63 Members of Parliament sit, indicated the seriousness with which it was treated.

\section{Heimildaskrá}

Alcoa (e.d.). „Iceland.“ Sótt af https://www.alcoa.com/iceland/ic.

Auður H. Ingólfsdóttir, Dorvarður Árnason, Jukka Siltanen og Hjalti Jóhannesson (2019). Náttúruvernd og byggðapróun: Áhrif verndarsvaða á grannbyggðir. Reykjavík: Hagfræðistofnun.

Auður Ingólfsdóttir (2008). „Environmental security and small states.“, í C. Archer, A.J.K. Bailes og A. Wivel (ritstj.), Small States and International Security (bls. 80-92). New York: Routledge.

Ásgeir Jónsson, Ásdís Kristjánsdóttir og Illugi Gunnarsson (2018). Framtio islenskrarpeningastefnu. Reykjavík: Forsætisráðuneytið.

Carlsson, F. og Johannsson-Stenman, O. (2000). „Willingness to pay for improved air quality in Sweden", Applied Economics 32, 661-669.

Diekmann, A. og Franzen, A. (1999). „The Wealth of Nations and Environmental Concern“, Environment and Behavior 31, 540-549.

Dunlap, R. E. og Van Liere, K.D. (1978). ,"The "New Environmental Paradigm“: A proposed measuring instrument and preliminary results", The Journal of Environmental Education 9(4), 10-19.

Dunlap, R. og Mertig, A.G. (1997). „Global Environmental Concern: An Anomaly for Postmaterialism“, Social Science Quarterly 78, 24-29.

Dunlap, R.E. (2008). „The New Environmental Paradigm Scale: From Marginality to Worldwide Use“, Journal of Environmental Education 40(1), 3-18.

Dunlap, R.E. (2015). „Environmental sociology“, International Encyclopedia of the Social \& Behavioral Sciences 2(7), 796-803.

Dunlap, R.E. (2017). „Foreword: A brief history of sociological research on environmental concern“, 1 A. Telešienè og M. Gross (ritstj.), Green European. Environmental Behaviour and Attitudes in Europe in a Historical and Cross-Cultural Comparative Perspective (bls. xviiii-xxvi). New York: Routledge.

Fairbrother, M. (2013). „Rich People. Poor People, and Environmental Concern: Evidence across Nations and Time“, European Sociological Review 29(5), 910-922.

Fairbrother, M. (2017). „When Will People Pay to Pollute? Environmental Taxes, Political Trust and Experimental Evidence from Britain“, British Journal of Political Science 49, 661-682.

Gelissen, J. (2007). „Explaining Popular Support for Environmental Protection: A Multilevel Analysis of 50 Nations", Environment and Behavior 39(3), 392-415.

Grenstad, G. og Wollebaek, D. (1998). „Greener Still?: An Empirical Examination of Eckersley's Ecocentric Approach", Environment and Behavior 30(5), 653-675.

Guerra, J., Schmidt, L. og Valente, S. (2017). „Dilemmas of Sustainability in Turbulent Times. The 
Portugese Case in Context", í A. Telešienė og M. Gross (ritstj.), Green European. Environmental Behaviour and Attitudes in Europe in a Historical and Cross-Cultural Comparative Perspective (bls. 221-243). New York: Routledge.

Hagfræðideild Landsbankans (2013). „,¡jóðhagslegt mikilvægi ferðapjónustunnar mun aukast verulega á næstu árum." Sótt af https://www.landsbankinn.is/Uploads/Documents/Hagsja/2013-11-29-Ferdathjonusta.pdf

Hardarson, O.Th. (1995). „Iceland“, European Journal of Political Research 28, 369-987.

Helgi Hallgrímsson. (2010). „, Páttaskil í náttúruvernd á Íslandi um 1970 og starfsemi náttúruverndarsamtaka“, Náttúrufradingurinn 79-80(1-49), 29-36.

Howell, S.E. og Laska, S.B. (1992). „The Changing Face of the Environmental Coalition: A Research Note“, Environmental Behavior 24(1), 134-144.

Iðnaðarráðuneytið (2009). Ábrif stóriðjuframkvamda á islensket efnahagslif. Sótt af https://www.stjornarradid.is/media/atvinnuvegaraduneyti-media/media/Rafraen_afgreidsla/2009-07-ahrif-storidjuframkvaemda-isl-efnahagslif.pdf

Inglehart, R. (1983). „The persistence of materialist and post-materialist value orientations: comments on Van Deth's analysis“, European Journal of Political Research 11(1), 81-91.

Inglehart, R. (1990). Culture Shift In Advanced Industrial Society. United States: Princeton University Press.

Inglehart, R. (1995). „Public Support for Environmental Protection: Objective Problems and Subjective Values in 43 Societies“, Political Science and Politics 28(1), 55-72.

Inglehart, R., (2008). „Changing values among Western publics from 1970 to 2006“, West European Politics 31(1-2), 130-146.

IPCC (2013). Climate change 2013: The Physical Science Basis. Contribution of working group I to the Fifth Assessment Report of the Intergovernmental Panel on Climate Change. Cambridge og New York: Cambridge University Press.

Ísak Ólafsson (1990). „Ál, ál og ekkert nema ál,“ Djóðviljïnn, 28. september.

Jón Ólafsson (2006). „Siðfræði andstöðunnar og ævintýrið mikla“, Skírnir 180, 421-448.

Karl Benediktsson (2008). „Moving Places: The Emotional Politics of Nature“, í J.O. Bærenholdt og B. Granås (ritstj.), Mobility and Place. Enacting Northern European Peripheries (bls. 205-217). Aldershot: Ashgate.

Kennedy, E.H., Beckley, T.M., McFarlane, B.L. og Nadeau, S. (2009). „Why We Don’t “Walk the Talk”: Understanding the Environmental Values/Behaviour Gap in Canada“, Human Ecology Review 16(2), 151-160.

Kenny, J. (2020). „Economic conditions and support for the prioritisation of environmental protection during the Great Recession“, Environmental Politics 29(6), 937-958.

Lög um stjórn fiskveiða nr. 38/1990.

McCright, A.M. og Dunlap, R.E. (2011). „Cool Dudes: The Denial of Climate Change among Conservative White Males in the United States“, Global Environmental Change 21(4), 1163-1172.

McCright, A.M. og Dunlap, R.E. (2013). „Bringing Ideology in: The Conservative White Male Effect on Worry about Environmental Problems in the USA“, Journal of Risk Research 16(2), 211-226.

McCright, A.M. og Xiao, C. (2014). „Gender and Environmental Concern: Insights from Recent Work and for Future Research“, Society \& Natural Resources 27(10), 1109-1113.

Minteer, B.A. og Manning, R.E. (1999). „Pragmatism in Environmental Ethics: Democracy, Pluralism, and the Management of Nature“, Environmental Etbic 21(2), 191-207.

Morgunblaðið (1999). „Eitt stærsta hagsmunamál Austurlands“, Morgunbladið, 27. febrúar. Sótt af https:/ / timarit.is/page/1928682?iabr=on\#page/n0/mode/2up

Neymayer, E. (2003). „Are left-wing party strength and corporatism good for the environment? Evidence from panel analysis of air pollution in OECD countries“, Ecological Economics 45, 203-220.

Nordic Council of Ministers (2018). Structural Adjustment and Regulations of Nordic Fisheries until 2025. Sótt af http://norden.diva-portal.org/smash/get/diva2:1253233/FULLTEXT01.pdf

OECD (2001). OECD Environmental Performance Reviews: Iceland 2001. París: OECD Publishing. 
OECD (2011). Towards green growth. A summary for policy makers. París: OECD Publishing.

Ólafur P. Hardarson og Gunnar Helgi Kristinsson (2003). „Iceland“, European Journal of Political Research 42, 975-978.

Schultz, P.W. (2001). „The Structure of Environmental Concern: Concern for Self, Other People, and the Biosphere", Journal of Environmental Psychology 21(4), 327-339.

Siltanen, J. (2018). Ábrif friðlýstra svaða á framleiðslu og atvinnu i nasta umbverfi. Reykjavík: Hagfræðistofnun.

Skúli Magnússon (1997). „Um stjórnskipulega eignarréttarvernd aflaheimilda“, Úlfjótur - tímarit laganema 3, 588-619.

Sóllilja Bjarnadóttir (2020). Do people behave as their family and friends? The role of social networks for pro-environmental behavior in Iceland (meistararitgerð). Reykjavík: Háskóli Íslands. Sótt af https://skemman. is/handle/1946/36982

Stern, P.C. og Dietz, T. (1994). „The Value Basis of Environmental Concern“, Journal of Social Issues 50, 65-84.

Stjórnarráð Íslands (2021). „24 aðgerðir í átt að hringrásarhagkerfi.“ Sótt af https://www.stjornarradid. is/efst-a-baugi/frettir/stok-frett/2021/01/12/24-adgerdir-i-att-ad-hringrasarhagkerfi/

Sustainable Europe Research Institute (2009). Overconsumption? Our use of the world's natural resources. Vienna: SERI.

Telesiene, A. og Gross M. (2017). Green European. Environmental Behaviour and Attitudes in Europe in a Historical and Cross-Cultural Comparative Perspective. New York: Routledge.

Torgler, B. og Garcia-Valiñas, M. (2007) „The determinants of individuals' attitudes towards preventing environmental damage", Ecological Economics 63, 536-552.

Torgler, B. og Garcia-Valiñas, M. A. and Macintyre, A. (2008). „Differences in Preferences Towards the Environment: The Impact of a Gender, Age and Parental Effect“, Nota di Lavoro 18.

Tremblay Jr., K.R. og Dunlap, R.E. (1978). „Rural-Urban Residence and Concern with Environmental Quality: A Replication and Extension“", Rural Sociology 43(3), 474-491.

Umhverfisstofnun (e.d.). „Hringrásarhagkerfið.“ Sótt af https://ust.is/graent-samfelag/graenn-lifstill/ hringrasarhagkerfid/

Unnur Birna Karlsdóttir (2010). Dar sem fossarnir falla. Náttúrusýn og nýting fallvatna á Íslandi 1900-2008. Reykjavík: Hið íslenska bókmenntafélag.

Walpole, M., Van Strien, A.J., Collen, B. og Scharlemann, J.P.W. (2010). „Global Biodiversity: Indicators of Recent Declines“, Science 328, 1164-1168.

Wray-Lake, L., Flanagan, C.A. og Osgood, D.W. (2010). „Examining Trends in Adolescent Environmental Attitudes, Beliefs, and Behaviors Across Three Decades“, Environment and Behavior 42(1), 61-85.

Xiao, C. og McCright, A.M. (2015). „Gender Differences in Environmental Concern: Revisiting the Institutional Trust Hypothesis in the USA“, Environment and Behavior 47(1), 17-37.

Xiao, C. og McCright, A.M. (2007). „Environmental Concern and Sociodemographic Variables: A Study of Statistical Models“, The journal of Environmental Education 38(2), 3-14.

porvarður Árnason (2004). „Umhverfisvitund Îslendinga“, Landabréfið 20(1), 3-24.

porvarður Árnason (2005). Views of Nature and Environmental Concern in Iceland (doktorsritgerð). Linköping: Linköpingsuniversitet. 
Sóllilja Bjarnadóttir, Inga Rún Sæmundsdóttir,

Sigrún Ólafsdóttir, porvarđur Árnason og

Guðbjörg Andrea Jónsdóttir
STJÓRNMÁL

STJÓRNSÝSLA

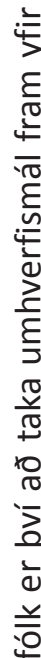

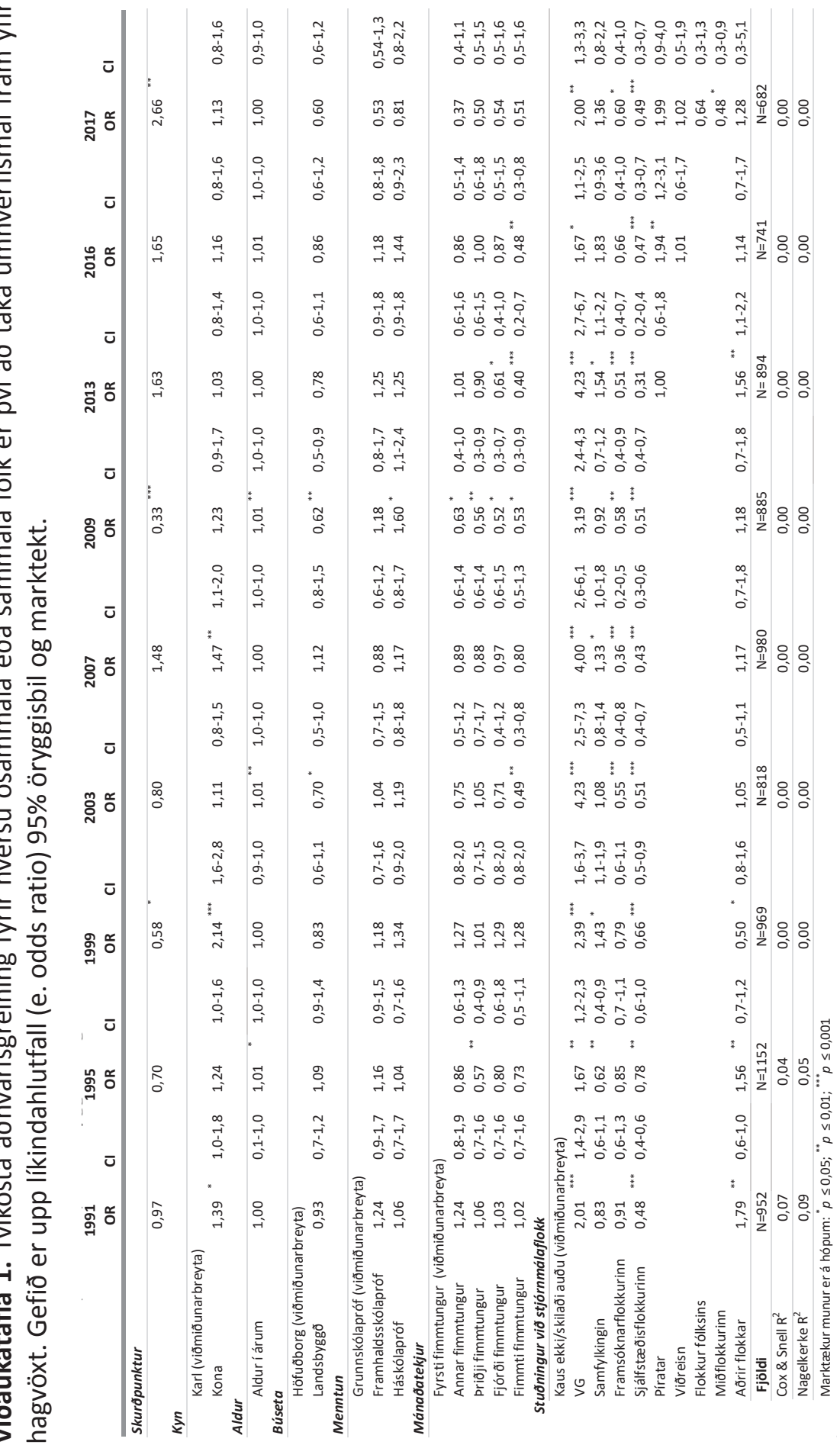




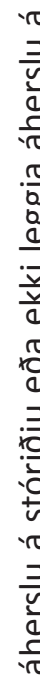

西

ro

\section{.}

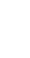

(1) 
$\frac{1}{\frac{1}{2}}$

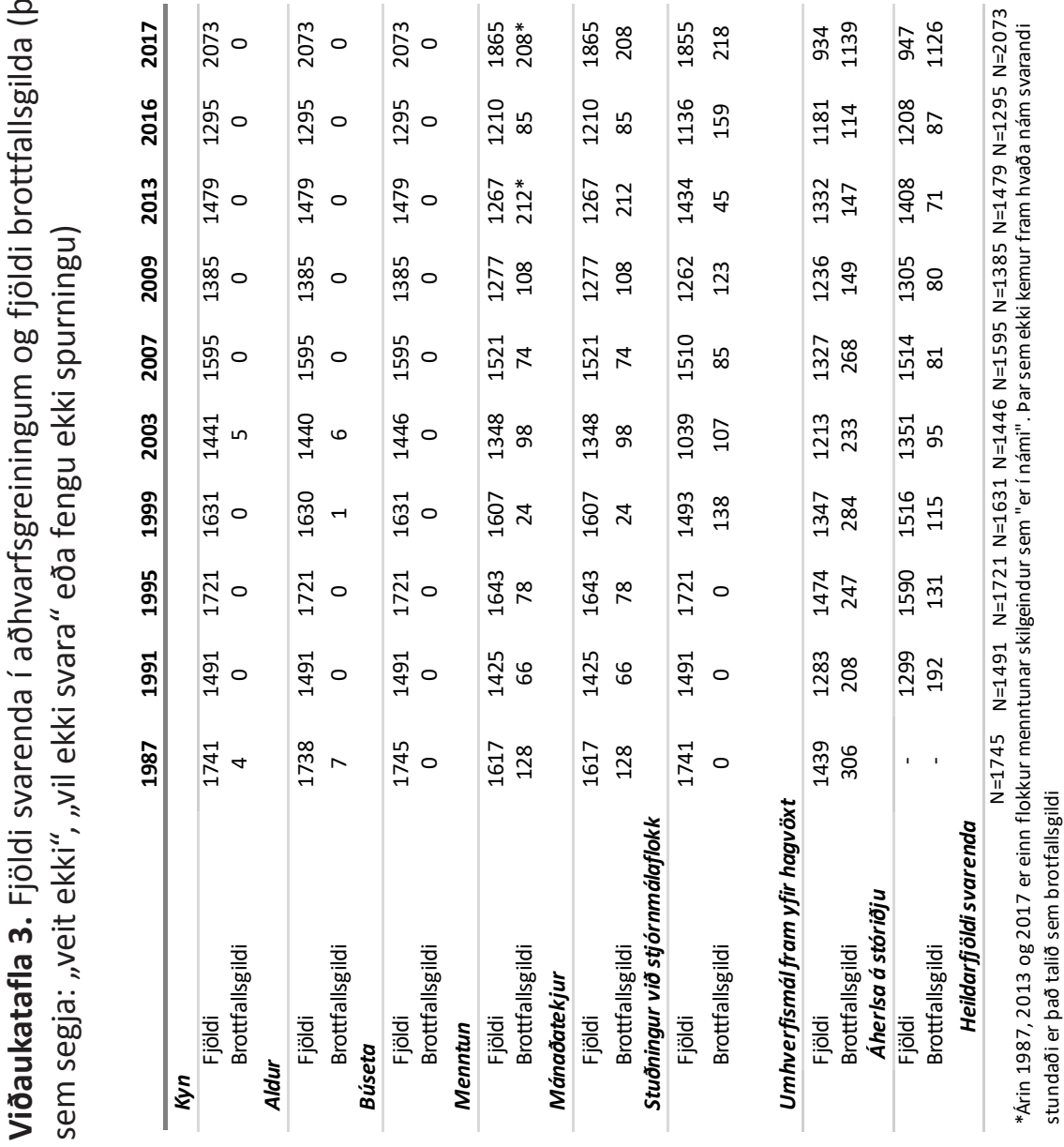


